This is postprint version of the article:

Mattalia, G., Sõukand, R., Corvo, P., \& Pieroni, A. (2019). Scholarly vs. Traditional Knowledge: Effects of Sacred Natural Sites on Ethnobotanical Practices in Tuscany, Central Italy. Human Ecology, 47(5), 653-667.

\title{
Scholarly vs. Traditional Knowledge: effects of Sacred Natural Sites on ethnobotanical practices in Tuscany, Central Italy
}

\author{
Giulia Mattalia $^{1,2^{*}}$, Renata Sõukand ${ }^{2}$, Paolo Corvo ${ }^{1}$, Pieroni Andrea ${ }^{1}$ \\ 'University of Gastronomic Sciences, Piazza Vittorio Emanuele II 9, I-12042 Pollenzo, Bra, \\ Italy \\ 2Department of Environmental Sciences, Informatics and Statistics, Ca' Foscari University of \\ Venice, Via Torino 155, I-30172 Mestre (Venezia), Italy \\ *Corresponding author giulia.mattalia@unive.it
}

\begin{abstract}
Sacred Natural Sites (SNSs), found in all inhabited continents, are cultural landscapes of spiritual significance for the local communities. As they are believed to influence Traditional Ecological Knowledge (TEK), we documented the use of wild and semi-domesticated plants for food and medicine in four villages located at different distances from SNSs in Central Italy. Results may indicate that SNSs, which have been managed and inhabited for centuries by monastic communities, have had a negative impact on the local TEK, as the communities located near SNSs reported fewer folk plant uses than those living further from the same SNSs. One possible explanation for this finding is that the Scholarly Knowledge (SK) held by the monastic communities of SNSs competed with the TEK of the surrounding villages and this resulted in a smaller body of plant-related folk knowledge, practices and beliefs retained by the people living in the vicinity of SNSs.

Despite the well-recognized importance of SNSs as remarkable biodiversity reservoirs, they may have been detrimental to the continuous, dynamic practicing of TEK. Further studies should address the past and current mechanisms of competition between TEK and SK in terms of both daily practices and beliefs/theoretical knowledge.
\end{abstract}

\section{Keywords}

Ethnobotany; Ethnomedicine; Traditional Ecological Knowledge; Sacred Natural Sites; Tuscany

\section{Introduction}

Traditional cultural landscapes in the Mediterranean Basin are the result of centuries-long evolution intertwined with social-ecological systems (Fischer et al. 2012; Plieninger and Bieling 2012). Sacred Natural Sites (SNSs) are cultural landscapes defined as "portions of land or water holding spiritual significance for people and communities" (Wild and McLeod 2008). SNSs can be found in all inhabited continents (Hughes and Chandran 1998) and sacred groves date back to pre-agricultural times (Gadgil and Vartak 1982). Sacred Natural Sites encompass a wide range of rituals, socio-cultural systems, faiths and beliefs (Verschuuren 2010). Dafni (2007) classified sacred places into artificial and natural objects, illustrating his statement with a citation from Turner (1979), who describes them as the meeting points of realms "set in a vertical dimension as ladders, poles and pillars, trees and hills". The division proposed by Dafni (2007) is somewhat ambivalent as in modern environments differentiation between natural and artificial is a matter of point of view. SNSs were well known in polytheistic religions and served as points of interaction between human and divine, seen as mediators of signs from immortal to mortal beings (see also Dafni 2007). Some well-established SNSs were later converted into 
This is postprint version of the article:

Mattalia, G., Sõukand, R., Corvo, P., \& Pieroni, A. (2019). Scholarly vs. Traditional Knowledge: Effects of Sacred Natural Sites on Ethnobotanical Practices in Tuscany, Central Italy. Human Ecology, 47(5), 653-667.

Christian sites in order to promote religious conversion (see Jonuks 2013 and references within).

Many studies related to SNSs have been carried out in Asia (Mody 2018 and references within) and Sub-Saharan Africa (Agyeman et al. 2016; Alohou et al. 2017; Daye and Healey 2015; Doffana, 2017; Nganso et al. 2012), while only a few, yet increasing number of, publications have focused on the Mediterranean Basin, including Greece (Avtzis et al. 2018; Stara et al. 2015), Morocco (Agyeman et al. 2016; Deil et al. 2005), Cyprus (Lardos and Heinrich 2013), and Italy (Frascaroli 2013; Frascaroli et al. 2014; Schmid et al. 2015).

The majority of the studies carried out in the Mediterranean Basin addressed the importance of SNSs as reservoir of biodiversity, whereas Frascaroli et al. (2014) examined the historical connection between SNSs and pastoralism. Frascaroli and Verschuuren (2016) pointed out the role of SNSs in sustaining traditional ecological knowledge (TEK). However, the relationship between SNSs and TEK remains underexplored in Western contexts. Nevertheless, if the relationship between SNSs and knowledge related to medicinal plants has, as of yet been little discussed in other geographical contexts, the relationship between SNSs and knowledge related to wild food plants has been partly explored by a study carried out in Cyprus (Lardos and Heinrich, 2013).

Research addressing medicinal plant knowledge at SNSs has also been carried out in Ethiopia by Teklehaymanot et al. (2007), in which the medical plant knowledge of the people living close to an Ethiopian Orthodox monastery was investigated; and it was found that local herbalists acquired the knowledge and use of medicinal plants from the monastic community. Thus, this knowledge was passed down secretively from one generation to the next. Actually, illustrated codices, often influenced by Hippocratic and Galenic medicine, were crucial sources for monastic medicine (Lardos and Heinrich 2013; Mądra Gackowska et al. 2018; Medeiros and de Albuquerque 2012; Niederer 2005). Such ancient medicinal knowledge was then adapted to local conditions (Dal Cero et al. 2014). Such an osmotic phenomenon perpetuated through the centuries by the close contact of monastic communities with neighboring communities (Lardos and Heinrich, 2013) has been fostered by pilgrimages which have contributed immensely to the spread of knowledge, especially during the Middle Ages (Kristjánsdóttir et al. 2014).

Against this background, we aimed to understand the effects of two Tuscan SNSs on traditional ecological knowledge. Tuscany has an important religious heritage due in part to its proximity to the Vatican, and it is, in fact, crisscrossed by many old pathways such as the Via Francigena, an ancient pilgrimage route that in Medieval times connected Canterbury to Rome.

Therefore, we aimed to assess the influence of two Tuscan SNSs (Madonna del Faggio in Pieve Santo Stefano and Monte Oliveto Maggiore in Asciano) on traditional knowledge related to wild and semi-domesticated plant food and medicinal preparations. Specifically our goals were:

- to document the uses of wild and semi-domesticated plants for food and medicinal preparations of two communities located close to and distant from the selected SNSs;

- to collate the collected ethnobotanical information in order to evaluate the influence of these selected SNSs on the traditional ecological knowledge of the communities living in the vicinity. 
This is postprint version of the article:

Mattalia, G., Sõukand, R., Corvo, P., \& Pieroni, A. (2019). Scholarly vs. Traditional Knowledge: Effects of Sacred Natural Sites on Ethnobotanical Practices in Tuscany, Central Italy. Human Ecology, 47(5), 653-667.

We argue that SNSs inhabited by monastic communities influence the TEK related to wild and semi-domesticated plants for medicinal and food preparations of the communities living in the surrounding area.

This research was conducted within the framework of the PRIN project titled "Biodiversity and ecosystem services in Sacred Natural Sites" (BIOESSANS) funded by the Italian Ministry of Research. Indeed, one of the main aims of BIOESSANS is to investigate a representative sample of SNSs in order to explore their possible relationship with local biodiversity and traditional environmental knowledge.

\section{Material and Methods}

THE STUDY AREA (TOSCANY, ITALY)

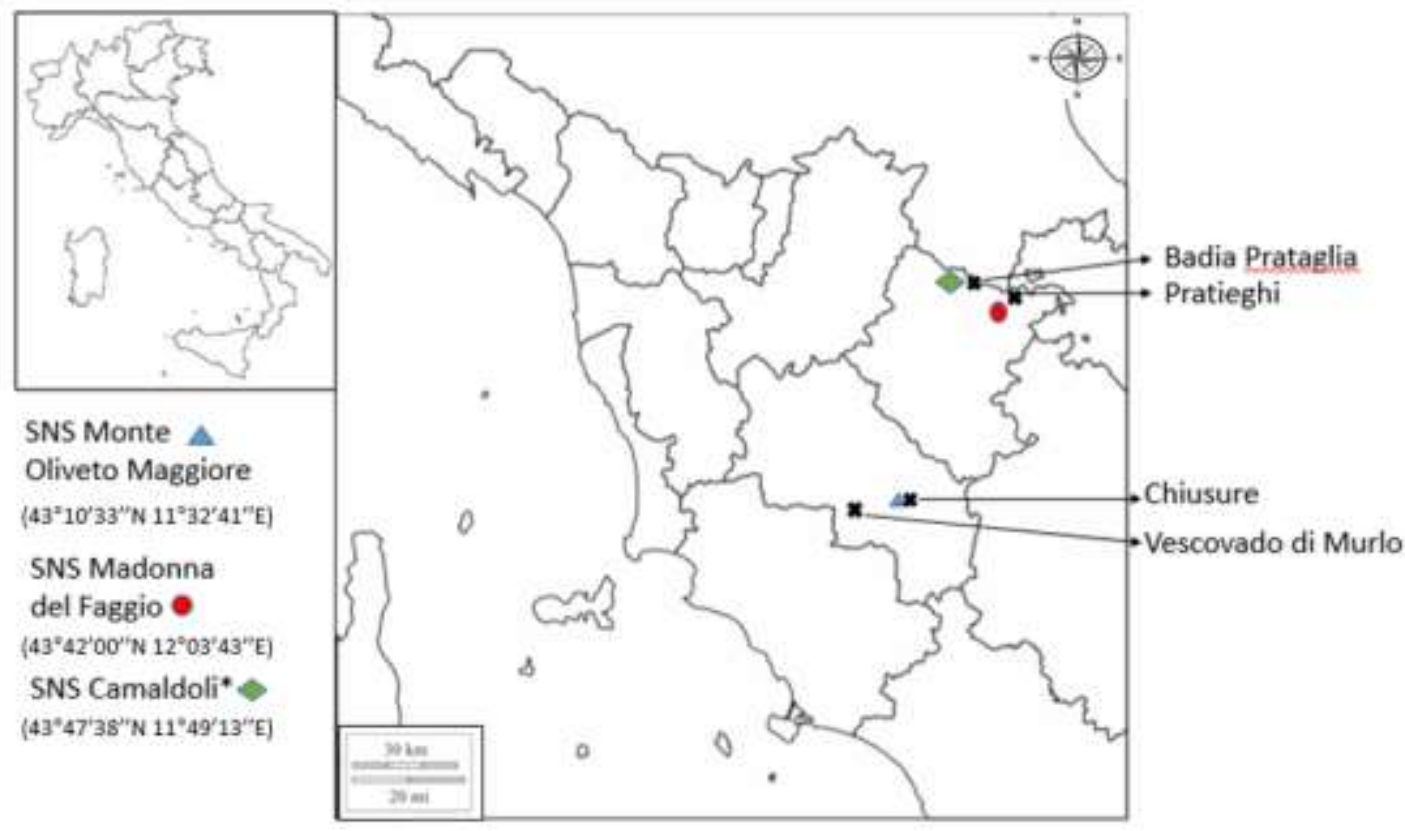

Figure 1 Map of the study area. * Relevance of the SNS of Camaldoli for this study is addressed in the framework section.

Study area

We conducted this study in two areas of Tuscany, the region in Central Italy whose capital city is Florence (Figure 1). The landscape is mainly hilly at the site of Monte Oliveto Maggiore, while it is mountainous at the site of the SNS of Madonna del Faggio.

Climatically, the two study areas are located in different zones. The study area of the SNS of Madonna del Faggio in Northern Tuscany has a temperate climate with rainy summers and cold winters $\left(1-2^{\circ} \mathrm{C}\right.$ average temperature in January), while the study area of the SNS of Monte Oliveto Maggiore is characterized by a temperate climate with dry summers and mild winters $\left(6^{\circ} \mathrm{C}\right.$ average temperature in January).

\section{Locations of the Sacred Natural Sites}

The SNS of Monte Oliveto Maggiore is inhabited by Benedictine monks, while Madonna del Faggio has never been home to a monastic community. 
The SNS of Monte Oliveto Maggiore is located in Southern Tuscany, in the municipality of Asciano. Benedictine monks built this SNS in the XIV century and they have inhabited the location since then. Benedictines living in such communities devote their lives to prayer and work (Ora et labora). The monastic community must be economically self-sustaining and all monks must work to help support the monastery. This abbey had a sizeable portion of land devoted to agricultural activities such as viticulture and horticulture. Moreover, monks used to produce medicinal preparations and liquors, the production of which ended around 1950. Currently at Monte Oliveto Maggiore it is possible to buy some goods produced by the monks, including wine, liquor, grappa, chickpeas, spelt and olive oil; medicinal preparations are also available but they are produced by other Italian monastic communities.

Chiusure is a village of around 200 inhabitants located $400 \mathrm{~m}$ asl and only $2 \mathrm{~km}$ away from the SNS. Many elderly people of the village worked for the monks in some capacity, as both farmers and employees. Nowadays Chiusure is a tourist destination with numerous cafés and restaurants.

Vescovado di Murlo is a village of 800 inhabitants located $300 \mathrm{~m}$ asl. It lies $13 \mathrm{~km}$ away, as the crow flies, from the Abbey of Monte Oliveto Maggiore. The toponym attests to the fact that it formerly belonged to the Archbishop of Siena (in Italian "vescovo" and therefore Vescovado). As it is the main village of the municipality of Murlo, it has many services such as minimarkets, bakeries, cafés, and restaurants.

The SNS of Madonna del Faggio is located in Northern Tuscany, in the municipality of Pieve Santo Stefano. This hermitage was built in the XV century after the Virgin Mary appeared to a young girl and offered her some strawberries. According to the writings on the building, this apparition occurred in 1516. At present, the hermitage is located in a hunting reserve, although it is accessible via some pathways. It is very small and surrounded by a few Fagus trees, from which its name likely derives.

Pratieghi is a peripheral village of less than 50 inhabitants located 6 kilometers from the SNS of Madonna del Faggio. The local community consists of a large number of retired people, and, seasonally, some Tuscan tourists. The village is located $850 \mathrm{~m}$ asl in the Tusco-Emilian Apennines and its economy is based on agricultural activities. A local family manages the café, minimarket, restaurant and hotel in the center of the village. The village name derives from the Italian words "prati e laghi" meaning meadows and lakes, due to the availability of both grasslands and water, which made this place suitable for pastoral activities and animal breeding.

Badia Pratalda is a peripheral village of about 600 inhabitants. It is located $19 \mathrm{~km}$ as the crow flies from the SNS of Madonna del Faggio. It used to be a popular mountain tourist destination in the last century, due also to its proximity to the Adriatic coast and the Po Plain. The village lies within the Foreste Casentinesi, Monte Falterona, Campigna National Park at an altitude of $835 \mathrm{~m}$ asl. Its name means "the abbey of the meadow", and, indeed, in the center of the village there is a millennium-old abbey founded in 986 by some Benedictine monks from the Abbey of Montecassino, in Latium. This sacred site was built a few years before the well-known Camaldoli hermitage (1023), which lies just few kilometers away.

Data collection and analysis

Fieldwork was carried out between September 2017 and April 2018 and a total of 61 interviews were conducted around the two SNSs. 


\begin{tabular}{|l|l|l|}
\hline SNS & $\begin{array}{l}\text { Close community (<10 km from } \\
\text { SNS) }\end{array}$ & $\begin{array}{l}\text { Distant community } \\
<\mathrm{x}<20 \mathrm{~km} \text { from SNS) }\end{array}$ \\
\hline $\begin{array}{l}\text { Madonna del Faggio (Pieve Santo } \\
\text { Stefano, AR) }\end{array}$ & $\begin{array}{l}\text { Pratieghi (Badia Tedalda, AR) } \\
16 \text { interviews }\end{array}$ & $\begin{array}{l}\text { Badia Pratalda (Poppi, AR) } \\
15 \text { interviews }\end{array}$ \\
\hline $\begin{array}{l}\text { Abbazia di Monte Oliveto } \\
\text { Maggiore (Asciano, SI) }\end{array}$ & $\begin{array}{l}\text { Chiusure (Asciano, SI) } \\
15 \text { interviews }\end{array}$ & $\begin{array}{l}\text { Vescovado di Murlo (Murlo, SI) } \\
15 \text { interviews }\end{array}$ \\
\hline
\end{tabular}

Purposive and snowball sampling methods were used in the selection of informants. We interviewed 17 women and 14 men at the SNS of Madonna del Faggio, while at the SNS of Monte Oliveto Maggiore we conducted interviews with 20 women and 10 men, mainly elderly individuals at both sites. The Code of Ethics of the International Society of Ethnobiology was strictly followed, and prior informed consent was received orally. Interviews were conducted in the Italian language; however, some interviewees responded in a local dialect. We collected qualitative and quantitative data about local wild and semi-wild plants gathered now or in the past for culinary purposes, as well as recipes, plant parts used and the modes of preparation and consumption. Subsequently, we asked informants to indicate remedies for treating illnesses by naming each part of the body. Interviews were semi-structured, and an in-depth conversation was conducted when possible. Whenever possible, informants were asked to show mentioned plants around the house in order to harvest voucher specimens for herbarium preparation. The mentioned species were collected, when available, and identified according to "Flora d'Italia" (Pignatti, 1982). Vouchers bear the numbers UNISGTOS001-038 and are deposited at the University of Gastronomic Sciences. Taxonomic identification, botanical nomenclature, and family assignments followed the Flora Europaea (Tutin et al. 1964), The Plant List database (2013), and Angiosperm Phylogeny Group IV (Stevens 2015). Data were assembled in an Excel database and structured in the form of detailed use reports.

\section{Research framework}

This research was conducted within the framework of the PRIN project titled "Biodiversity and ecosystem services in Sacred Natural Sites". Four research institutions contributed to different aspects of this topic. Therefore, together with the other partner institutions we selected two SNSs in Tuscany in order to study the influence of SNSs on the TEK of the communities living in the surrounding area, while the work of other groups will address the influence of SNSs on biodiversity. However, when conducting the initial fieldwork at Madonna del Faggio, we realized that individuals of the two communities (Pratieghi and Badia Prataglia) were often referring to SNSs other than the one we had selected, especially to that of Camaldoli. Indeed, the area is densely populated by important SNSs such as the Franciscan sanctuary of La Verna (Chiusi della Verna), the sanctuary of Santa Maria del Sasso (Bibbiena), the hermitage of Cerbaiolo (Pieve Santo Stefano) and the hermitage and shrine of Camaldoli (Poppi). The famous Camaldoli shrine and hermitage was quite significant to our interviewees, as it lies just $4 \mathrm{~km}$ away from Badia Pratalda and $23 \mathrm{~km}$ away from Pratieghi. Therefore, we also decided to consider this SNS to serve as a comparison to Monte Oliveto Maggiore, as both sites are millennium-old shrines managed by Benedictine monks. The Camaldoli shrine was founded in 
This is postprint version of the article:

Mattalia, G., Sõukand, R., Corvo, P., \& Pieroni, A. (2019). Scholarly vs. Traditional Knowledge: Effects of Sacred Natural Sites on Ethnobotanical Practices in Tuscany, Central Italy. Human Ecology, 47(5), 653-667.

1012, and since then a community of Benedictine monks has lived in the area. The pharmacy of Camaldoli was (and still is) renowned as was the hospital, which treated people living in the surrounding area and wayfarers for many centuries. Currently, this SNS is an important religious point and tourist attraction. The monastic community of Camaldoli produces a wide variety of goods, mainly medicinal and cosmetic.

\section{Results}

Ethnobotany of the SNS of Monte Oliveto Maggiore

Eighty taxa belonging to 41 families were mentioned by individuals from the two communities in the near and distant surroundings of the SNS of Monte Oliveto Maggiore. Specifically, the inhabitants of Vescovado di Murlo and Chiusure reported the use of 68 and 52 species, respectively. Most of the taxa are common to the two communities; however, the interviewees from Chiusure mentioned around 22\% fewer taxa than did those from Vescovado di Murlo.

In Vescovado di Murlo, we recorded 20 food uses and 28 medicinal uses, while in Chiusure we recorded 16 food uses and 18 medicinal uses. Therefore, close to the SNS we found $20 \%$ fewer food uses and $35 \%$ fewer medicinal uses compared to the more distant location. The most common food preparations in both Vescovado and Chiusure include plants eaten raw in salads, raw plants used as seasoning, and fruits used for making jams (Figure 2). In each community, at least seven taxa were dedicated to these uses. In addition, in Vescovado di Murlo there were two other popular categories, namely taxa used to make liquors and those for making omelets (seven species each). These taxa were not that important in Chiusure as liquor was only made with Juglans regia, and omelets were prepared with Urtica dioica, Ruscus aculeatus, Rubus ulmifolius and Clematis vitalba.

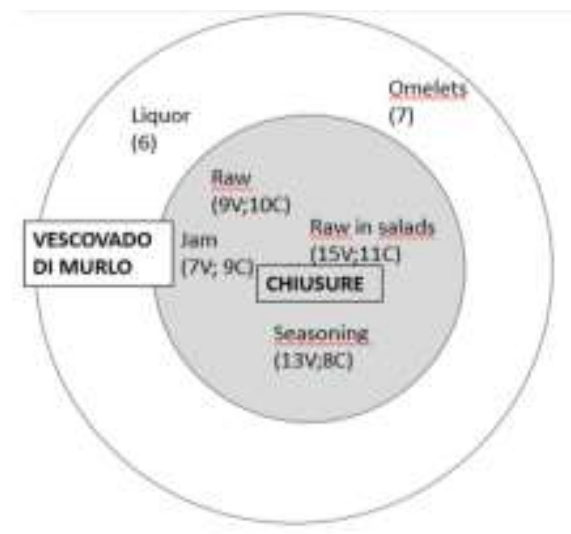

Figure 2 Mentioned taxa with at least five uses reported close to and distant from the SNS of Monte Oliveto Maggiore (number of uses per village are reported in brackets; $V=$ Vescovado, $C=$ Chiusure).

Regarding medicinal uses, the most common preparation in both communities was infusion, as we recorded 18 different infusions in Vescovado di Murlo and 13 in Chiusure. Poultice was another preparation common to the two communities. Other medicinal preparations include local application (Plantago lanceolata), maceration in olive oil (Hypericum perforatum), oral administration (Allium ursinum) and "carried in the pocket" (Cupressus spp. and Aesculus hippocastanum) in Vescovado di Murlo, and decoction (Equisetum arvense and Malva spp.), ointment (Arundo donax, Olea europaea, Rubus ulmifolius) and fomentation in Chiusure (Rosmarinus officinalis).

Ethnobotany of the SNS of Madonna del Faggio 
Fifty-eight taxa belonging to 31 families were mentioned by individuals in the two communities. Specifically, the inhabitants of Pratieghi reported the use of 45 species while in Badia Prataglia 36 species were used. The majority of the taxa are common to the two communities; however, the interviewees of Badia Pratalda mentioned around 25\% fewer taxa than those from Pratieghi.

In Pratieghi 13 food uses and 13 medicinal uses were mentioned, while interviewees from Badia Prataglia reported 10 food uses and 12 medicinal uses. The most common food uses in the two communities include taxa used to make jam or liquors, and taxa boiled or eaten raw. At least six taxa were mentioned in each community for each category (Figure 3 ). In addition, the use of seasoning plants (six taxa recorded) was important in Pratieghi, whereas in Badia Prataglia only Mentha spp. and Juniperus communis were utilized for this purpose.

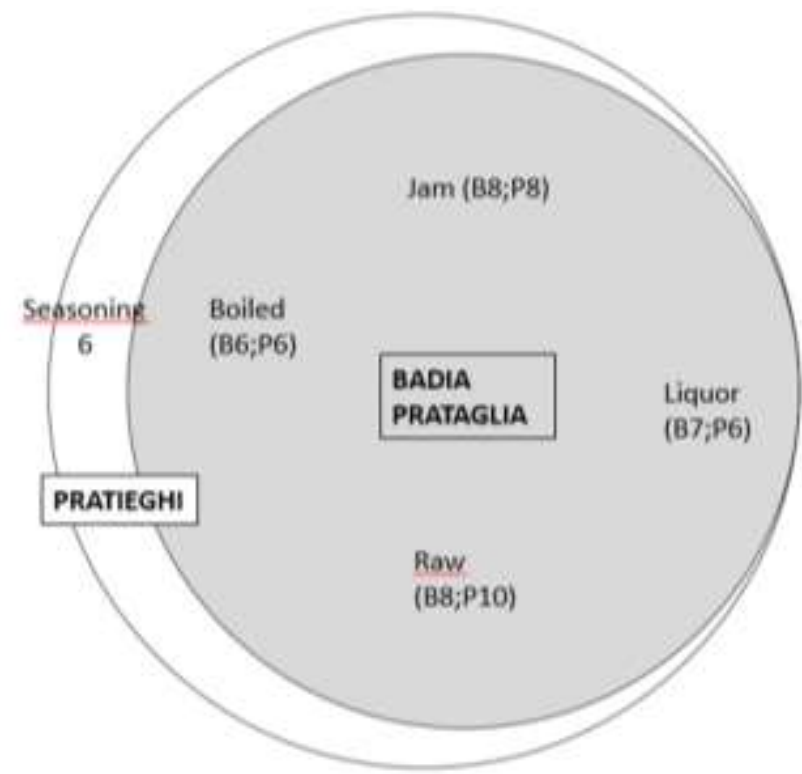

Figure 3 Mentioned taxa with at least five uses reported close to and distant from the SNS of Monte del Faggio (number of uses per village are reported in brackets; $B=$ Badia Prataglia, $P=$ Pratieghi).

In regard to medicinal uses, we recorded nine different infusions in Pratieghi but only six in Badia Prataglia. Also, two recipes for decoctions were mentioned in each community. Furthermore, local applications (Matricaria chamomilla), syrups (Fragaria vesca and Rubus idaeus) and leaf chewing (Malva spp.) were reported in Badia Prataglia, while maceration of Hypericum perforatum in olive oil was used in Pratieghi.

There were not many taxa used for both medicinal and food purposes. In both areas, many taxa were consumed raw, either in salads or as a snack. However, some taxa were also made into jams, and sometimes liquors or ravioli fillings. In Badia Prataglia syrup of wild forest fruits was also mentioned.

\section{Discussion}

Our results provide evidence for the influence of the selected SNSs on the TEK of the communities living in the surrounding area. The case of Monte Oliveto Maggiore, a SNS continuously inhabited for over a millennium, indicates that there is a negative correlation between proximity to SNSs and richness of TEK. In other words, communities living closer to 
SNSs inhabited by a monastic community have more limited TEK than communities living further away. This is also demonstrated by the analysis of the SNS of Camaldoli. Interviewees from Badia Prataglia, the closest village, which lies only a few kilometers away from the sacred site, reported around 25\% fewer taxa compared to that of Pratieghi (about $20 \mathrm{~km}$ away). This phenomenon may be due to the fact that people living in the vicinity of a SNS have relied on the monastic communities for both medical treatment and food, which in turn has led to an abandonment of time-consuming and sometimes knowledge-intensive practices, such as foraging for wild plants and their food and medicinal preparations. Indeed, this case study sheds light on the management of SNSs. It is important to note, however, that the existence of SNSs per se does not have a direct influence on the TEK of local communities. It is rather the longterm management of the monastic communities living in such SNSs that actually affects the TEK of local communities.

Sacred Natural Sites, especially those characterized by centuries-long continuous management, have been able to preserve rare texts and documents (Egea et al. 2015). As a result, through the study of these documents and in particular botanical and medicinal texts, monks (in our case, for example, the Benedictines) have been able to prepare medicinal preparations based on Hippocratic and Galenic medicine (Mądra Gackowska et al. 2018; Medeiros and de Albuquerque 2012). Monastic communities, therefore, used to produce medicinal preparations following the principles of scholarly knowledge (SK), which we define as a corpus of knowledge obtained through the study of historical written sources (mainly in Latin) and implemented in practice within monastic life and for the surrounding community. On the other hand, communities living in the surrounding area do not have access to such sources (due to both restricted physical access and the inability to read Latin), and thus their knowledge is generated through trial and error and then handed down orally from generation to generation (Berkes 1993). Therefore, monastic communities living at SNSs base their practices on SK, while surrounding communities base their practices on TEK. Thus, in contrast to (Frascaroli et al. 2014), we claim that, in the Catholic Mediterranean Basin, SNSs can be bastions of biocultural diversity but not TEK. We argue that SK not only does not contribute to TEK, but actually competes with it. This competition occurs asymmetrically since in Italy religious power has often played a crucial role in society as well. Indeed, medical care provided by monastic communities played a crucial social role in providing therapeutic aid to the communities living in the vicinity of the SNSs (Mądra Gackowska et al. 2018; Medeiros and de Albuquerque 2012). Therefore, the medicinal TEK of local communities and the medicinal SK of monastic communities came to compete. On one hand, the monastic medicinal preparations made using access-restricted knowledge, ingredients and technologies were passed on secretively within the SNS. On the other hand, TEK was based on largely accessible knowledge, ingredients and technologies. In fact, TEK encompasses a body of knowledge, practices and beliefs, while SK comprises mainly knowledge and some practices. In addition, TEK knowledge is primarily transmitted orally held by local communities, locally situated and highly variable, whereas SK is largely written, held by specific sectors of the population, and global and highly homogenized (Table 2).

Table 2 Comparison between Scholarly Knowledge and Traditional Ecological Knowledge in the Mediterranean context.

\begin{tabular}{|c|c|c|}
\hline & SK & TEK \\
\hline Definition & $\begin{array}{l}\text { Corpus of knowledge obtained through } \\
\text { the study of historical written sources } \\
\text { (mainly in Latin) and implemented in } \\
\text { its practice in monastic life }\end{array}$ & $\begin{array}{l}\text { Corpus of knowledge, practices and } \\
\text { beliefs obtained through empirical } \\
\text { observation and the accumulation of } \\
\text { facts by trial-and-error (Berkes 1999) }\end{array}$ \\
\hline Transmission & Written sources & Orally (Berkes 1999) \\
\hline
\end{tabular}


This is postprint version of the article:

Mattalia, G., Sõukand, R., Corvo, P., \& Pieroni, A. (2019). Scholarly vs. Traditional Knowledge: Effects of Sacred Natural Sites on Ethnobotanical Practices in Tuscany, Central Italy. Human Ecology, 47(5), 653-667.

\begin{tabular}{|l|l|l|}
\hline $\begin{array}{l}\text { Accessibility } \\
\text { (physical) }\end{array}$ & Low & High \\
\hline Language & $\begin{array}{l}\text { Ancient literary sources mainly in Latin } \\
\text { and Greek }\end{array}$ & Local language (Berkes 1999) \\
\hline $\begin{array}{l}\text { Technology } \\
\text { applied }\end{array}$ & High and not accessible & Low and accessible \\
\hline $\begin{array}{l}\text { Ingredients } \\
\text { used }\end{array}$ & Allochthonous and autochthonous & Autochthonous (Salick et al. 2006) \\
\hline Diffusion & Punctiform & Ubiquitarious \\
\hline
\end{tabular}

During fieldwork, we discovered that there was a close relationship between the villagers of Chiusure and the Abbey of Monte Oliveto Maggiore. Indeed, the shrine also owns many hectares of agricultural fields that have been cultivated for centuries by the inhabitants of Chiusure, under the supervision of the Benedictine monks. This tie is still strong and many local inhabitants referred to the use of the "miraculous plaster" of the monks, a compound of beeswax used to treat the skin and particularly to remove thorns. This SNS has mainly been devoted to agricultural activities and it established a pharmacy (which is now closed) only in the late XVI century. Therefore, the very small number of taxa reported in Chiusure may be partially due to the "food and medicinal security" ensured by the presence of the monastic community living at the SNS. Specifically, only one liquor preparation was mentioned by a single individual living close to the SNS (the widely known liquor of walnuts), while in Vescovado di Murlo six taxa were used for this purpose. Indeed, the SNS of Monte Oliveto Maggiore produced a famous liquor, and thus inhabitants of Chiusure probably did not feel the need (and/or did not have the adequate technology) to make it themselves. This somewhat contradicts the findings of (Teklehaymanot et al. 2007) who showed, in a different cultural and geographical context, that the knowledge of the people living close to the monastic community was higher than those further away as they acquired such knowledge from the monastic community. However, as (Teklehaymanot et al. 2007) did not succeeded in interviewing the monastic community and there were numerous herbalists in those villages who also had the power of influence and possessed extensive knowledge, it may be that the presence of the monastery simply influenced the awareness of the use of medicinal plants and villagers did not the directly borrow taxa and uses from the monks.

The SNS of Camaldoli was solely devoted to healing activities, as it also possessed a small hospital, dispensary and pharmacy. This specialization may also be a consequence of its location in the middle of the forest, which did not allow for the establishment of extensive agricultural activity. The healing specialization of this SNS is also reflected in the TEK of the inhabitants of Badia Prataglia. Only nine medicinal taxa were reported (mainly prepared as infusions). This is probably due to the proximity of the SNS, which provided local inhabitants with medical care. Medicinal preparations by monastic communities greatly differ from those reported by our interviewees (see also Egea et al. 2016). Indeed, SK often applies the use of allochthonous plant taxa, as also demonstrated in other contexts (Salick et al. 2006). These plants were generally cultivated and preserved within the shrine expressly for the preparation of medicinal remedies. In addition, SK made great use of alcohol-based solutions (e.g. grappa, liquors, see also Egea et al. 2015), as was also found in our study, and this is in contrast to the water-based solutions used by TEK holders (e.g. infusions, decoctions). Populations living close to the SNS rarely had access to expensive alcohol and they did not have the knowledge and technology for distilling it. Nevertheless, the relationship between TEK and SK has often been unequivocal. Monastic communities could draw TEK from local communities, while local communities could not always implement the knowledge originating from monastic communities due to their lack of access to many raw ingredients, technologies and adequate 
knowledge/education. However, a process of knowledge osmosis can also be sometimes observed. Four interviewees living in the vicinity of the SNS of Monte Oliveto Maggiore reported the unusual and quite complex preparation of an infusion made from the roots of Arundo donax, Rumex crispus, Knautia arvensis for treating liver and kidney stones. When asked from whom did they learn this recipe, the oldest interviewee claimed that once upon a time there were some families of "herbalists", while another interviewee exclaimed "Of course they made that recipe; they had books!". Both these claims might refer to the presence of the SNS, despite no longer being remembered by the local inhabitants. Therefore, as in the village of Chiusure, many people used to work in the monastery farm and some SK may have been transmitted to the local inhabitants over the time, which was later assimilated into TEK.

A particular example of knowledge osmosis is the case of "lacrima d'abeto", a liquor made from several plants including Abies alba, Piper nigrum, Thymus serpyllum, Elettaria cardamomum, Curcuma domestica, Pimpinella anisum, Angelica archangelica, Citrus aurantium, and Vanilla planifolia, that is produced by the Camaldoli monastic community. When some inhabitants of Badia Prataglia were asked about liquors they prepare, the interviewees reported "Monks make lacrima d'abeto!", as indeed most of the ingredients of that liquor come from allochthones taxa, not available to the local community. As we did not interview members of the monastic communities we do not have examples of osmosis from TEK to SK, from local to monastic communities. Nonetheless, Lardos and Heinrich (2013) argue that such knowledge osmosis could be the result of either a combination of SK learnt in monastic life and the TEK acquired in childhood or close contact with the surrounding communities.

However, this asymmetry mainly applies to medicinal knowledge as wild food knowledge has often been excluded from the "high" corpus of knowledge managed by monastic communities. Actually, back in the middle Ages, it was believed that God created plants to serve humankind, and thus herbalism was an often an intrinsic element of monastic life (Mądra Gackowska et al. 2018). In fact, the reason for a smaller number of food taxa reported close to SNSs may be found in the welfarism enacted by monastic communities and not in the competition between SK and TEK. Indeed the foraging of wild food plants requiring intensive practical knowledge within specific ecological conditions may be abandoned in favor of (cultivated) products that are provided or whose knowledge has been acquired from the monastic community.

\section{Conclusions}

Our study discussed the possible influence of three Tuscan SNSs on TEK related to wild and semi-domesticated plants for food and medicinal preparations. We found that SNSs managed and inhabited for centuries by monastic communities may have had a negative impact on the TEK of communities living in the surrounding areas. The communities situated close to SNSs report less TEK related to wild and semi-domesticated plants for food and medicinal preparations than those living further away. Indeed, SK held by monastic communities has surely diffused by osmosis into the surrounding TEK over the centuries, but it may have also competed with TEK, resulting in a smaller corpus of plant-related knowledge, practices and beliefs with respect to what would have been reasonable to expect. In addition, we found that certain natural ingredients managed within the monastic communities living in the SNS could also have contributed to shape the TEK of the surrounding populations. We conclude that, despite the well-recognized importance of SNSs as prominent biodiversity reservoirs, they may also have acted as agents of "homogenization" on the surrounding TEK, possibly in addition to other historical processes that normally restrict the variability and resilience of TEK (i.e. industrialization, globalization), especially for that concerning medicinal plants. Further studies should better address the mechanisms of competition of TEK and SK from a historical 
This is postprint version of the article:

Mattalia, G., Sõukand, R., Corvo, P., \& Pieroni, A. (2019). Scholarly vs. Traditional Knowledge: Effects of Sacred Natural Sites on

Ethnobotanical Practices in Tuscany, Central Italy. Human Ecology, 47(5), 653-667.

perspective and how this contributed to the current TEK of people living in the vicinity of inhabited

Sacred

Natural

Sites.

Acknowledgments

Special thanks to all the informants who kindly share their folk plant knowledge.

Funding

This research was funded by the Italian Ministry of Education, Universities and Research Funds for this study came from the MIUR through the PRIN project 'Biodiversity and ecosystem services in Sacred Natural Sites (BIOESSaNS)', Nr. 2015P8524C, as well as from the University of Gastronomic Sciences of Pollenzo, Italy.

Conflict of Interest

The authors declare that they have no conflict of interest.

\section{References}

Agyeman, Y., Saito, O., Seidu, G., and Otsuki, K. (2016). Provisioning ecosystem services-sharing as a coping and adaptation strategy among rural communities in Ghana's semi-arid ecosystem. Ecosystem Services, 19, 92-102.

Alohou, E. C., Gbemavo, D. S. J. C., Mensah, S., and Ouinsavi, C. (2017). Fragmentation of Forest Ecosystems and Connectivity Between Sacred Groves and Forest Reserves in Southeastern Benin, West Africa. Tropical Conservation Science, 10, 1-11.

Avtzis, D. N., Stara, K., Sgardeli, V., Betsis, A., Diamandis, S., Healey, J. R., Kapsalis E., Kati V., Korakis G., Marini Govigli V., Monokrousos N., Muggia L., Nitsiakos V., Papadatou E., Papaioannou H., Rohrer A., Tsiakiris R., Van Hotan K.S., Vokou D., Wong J.L.G., Halley, J. M. (2018). Quantifying the conservation value of Sacred Natural Sites. Biological Conservation, 222, 95-103.

Berkes, F. (1993). Traditional ecological knowledge in perspective. In Inglis, J Traditional ecological knowledge: concepts and cases. (Vol. 1) IDRC.

Dafni, A. (2007). Rituals, ceremonies and customs related to sacred trees with a special reference to the Middle East. Journal of Ethnobiology and Ethnomedicine, 3(1), 28.

Dal Cero, M., Saller, R., and Weckerle, C. S. (2014). The use of the local flora in Switzerland: A comparison of past and recent medicinal plant knowledge. Journal of Ethnopharmacology, 151(1), 253-264.

Daye, D. D., and Healey, J. R. (2015). Impacts of land-use change on sacred forests at the landscape scale. Global Ecology and Conservation, 3, 349-358.

Deil, U., Culmsee, H., and Berriane, M. (2005). Sacred groves in Morocco: A society's conservation of nature for spiritual reasons. Silva Carelica, 49, 185-201. 
This is postprint version of the article:

Mattalia, G., Sõukand, R., Corvo, P., \& Pieroni, A. (2019). Scholarly vs. Traditional Knowledge: Effects of Sacred Natural Sites on

Ethnobotanical Practices in Tuscany, Central Italy. Human Ecology, 47(5), 653-667.

Doffana, Z. D. (2017). Sacred natural sites, herbal medicine, medicinal plants and their conservation in Sidama, Ethiopia. Cogent Food and Agriculture, 3(1).

Egea, T., Signorini, M. A., Bruschi, P., Rivera, D., Obón, C., Alcaraz, F., and Palazón, J. A. (2015). Spirits and liqueurs in European traditional medicine: Their history and ethnobotany in Tuscany and Bologna (Italy). Journal of Ethnopharmacoly. 175.

Egea, T., Signorini, M. A., Ongaro, L., Rivera, D., de Castro, C., and Bruschi, P. (2016). Traditional alcoholic beverages and their value in the local culture of the Alta Valle del Reno, a mountain borderland between Tuscany and Emilia-Romagna (Italy). Journal of Ethnobiology and Ethnomedicine, 12(1), 27.

Fischer, J., Hartel, T., and Kuemmerle, T. (2012). Conservation policy in traditional farming landscapes. Conservation Letters, 5(3), 167-175.

Frascaroli, F. (2013). Catholicism and Conservation: The Potential of Sacred Natural Sites for Biodiversity Management in Central Italy. Human Ecology, 41(4), 587-601.

Frascaroli, F., Bhagwat, S., and Diemer, M. (2014). Healing Animals, Feeding Souls: Ethnobotanical Values at Sacred Sites in Central Italy. Economic Botany, 68(4), 438-451.

Frascaroli, F., and Verschuuren, B. (2016). Linking Biocultural Diversity and Sacred Sites: Evidence and Recommendations in the European Framework. In: Agnoletti M. and Emanueli F. (eds.), Biocultural Diversity in Europe, Environmental History 5, New York: Springer.

Gadgil, M., and Vartak, V. D. (1982). The sacred groves of Western Ghats in India. Economic Botany, 30(2), 152-160.

Hughes, J. D., and Chandran, M. D. S. (1998). Sacred groves around the earth: an overview. In P. S. Ramakrishnan, K. G. Saxena, and U. M. Chandrashekara (Eds.), Conserving the Sacred for Biodiversity Management. Science Publishers

Jonuks, T. (2013). Hiis-sites in Northern Estonia: Distinctive hills and plain fields. Archeologia Baltica, 15, 20-30.

Kristjánsdóttir, S., Larsson, I., and Åsen, P. A. (2014). The Icelandic medieval monastic garden did it exist? Scandinavian Journal of History, 39(5), 560-579.

Lardos, A., and Heinrich, M. (2013). Continuity and change in medicinal plant use: The example of monasteries on Cyprus and historical iatrosophia texts. Journal of Ethnopharmacology, 150(1), $202-214$.

Mądra Gackowska Gackowska K., Gackowski M., Główczewska Siedlecka E., Siedlecki Z., Ziółkowska S. (2018) Medications of medieval monastery medicine. Journal of Education, Health and Sport. 8 (9)1667-1674

Medeiros, M. F. T., and de Albuquerque, U. P. (2012). The pharmacy of the Benedictine monks: The use of medicinal plants in Northeast Brazil during the nineteenth century (1823-1829). Journal of Ethnopharmacology, 139(1), 280-286.

Mody, Z. (2018). Socio-ecology and the sacred: A comparative study of entanglement and natural sites in tropical Asia. Trent University.

Nganso, T. B., Kyerematen, R., and Obeng-Ofori, D. (2012). Review of biodiversity in sacred groves in Ghana and implications on conservation. Current Trends in Ecology, 3, 1-10. 
This is postprint version of the article:

Mattalia, G., Sõukand, R., Corvo, P., \& Pieroni, A. (2019). Scholarly vs. Traditional Knowledge: Effects of Sacred Natural Sites on Ethnobotanical Practices in Tuscany, Central Italy. Human Ecology, 47(5), 653-667.

Niederer, M. (2005). Der St.Galler Botanicus; Ein frühmittelalterliches Herbar; Kritische Edition, Übersetzung und Kommentar. (Lang, Euro). Bern.

Pignatti, S. (1982). Flora d'Italia, vol. 1-3. Bologna: Edagricole.

Plieninger, T., and Bieling, C. (2012). Resilience and the cultural landscape: understanding and managing change in human-shaped environments. Cambridge University Press.

Salick, J., Byg, A., Amend, A., Schmidt, H., Law, W., and Gunn, B. (2006). Tibetan Medicine Plurality. Economic Botany, 60(3), 227-253.

Schmid, B., Guarino, R., Frascaroli, F., Chiarucci, A., and Bhagwat, S. (2015). Shrines in Central Italy conserve plant diversity and large trees. Ambio, 45(4), 468-479.

Stara, K., Tsiakiris, R., and Wong, J. L. G. (2015). The Trees of the Sacred Natural Sites of Zagori, NW Greece. Landscape Research, 40(7), 884-904.

Stevens, P. F. 2015. Angiosperm Phylogeny Website, version 14. http://www.mobot.org/MOBOT/research/APweb/ (28 March 2019).

Teklehaymanot, T., Giday, M., Medhin, G., and Mekonnen, Y. (2007). Knowledge and use of medicinal plants by people around Debre Libanos monastery in Ethiopia. Journal of Ethnopharmacology, 111(2), 271-283.

The Plant List database 2013.

Turner, H. W. (1979). From temple to meeting house: The phenomenology and theology of places of worship. The Hague: Mouton

Tutin, T. G., Burges, N. A., Chater, A. O., Heywood, V. H., Valentine, D. H., Walters, S. M., and Webb, D. A. (1964). Flora Europaea. Cambridge University Press.

Verschuuren, B. (2010). Sacred natural sites: Conserving nature and culture. Routledge.

Table 3 List of recorded taxa and detailed use-reports for the villages of Chiusure (close) and Vescovado (distant) in the province of Siena; *Past uses.

\begin{tabular}{|c|c|c|c|c|c|}
\hline Botanical taxon, family, recorded name & $\begin{array}{l}\text { Parts } \\
\text { used }\end{array}$ & Chiusure & $\begin{array}{l}\text { Vescovado di } \\
\text { Murlo }\end{array}$ & $\begin{array}{l}\text { Chiusur } \\
\text { e } n=15\end{array}$ & $\begin{array}{l}\text { Vescovado } \\
\text { di Murlo } \\
n=15\end{array}$ \\
\hline $\begin{array}{l}\text { Aesculus hippocastanum L. (Sapindaceae) } \\
\text { Castagno d'India }\end{array}$ & Fruits & & $\begin{array}{l}\text { M: In the pocket to } \\
\text { treat hemorrhoids; } \\
\text { In the pocket to } \\
\text { treat flu }\end{array}$ & & 4 \\
\hline $\begin{array}{l}\text { Allium sativum L. (Amaryllidaceae) } \\
\text { Aglio selvatico }\end{array}$ & $\begin{array}{l}\text { Bulbs } \\
\text { and } \\
\text { leaves }\end{array}$ & & F: Seasoning & & 3 \\
\hline $\begin{array}{l}\text { Allium ursinum L. (Amaryllidaceae) } \\
\text { Aglio ursino }\end{array}$ & $\begin{array}{l}\text { Aerial } \\
\text { parts }\end{array}$ & & $\begin{array}{l}\text { M: Oral } \\
\text { administration to } \\
\text { lower blood } \\
\text { pressure } \\
\text { F: Sauce for pasta }\end{array}$ & & 2 \\
\hline Arbutus unedo L. (Ericaceae) & & $\mathrm{F}$ : Raw as a snack & $\begin{array}{l}\text { F: Raw as a snack; } \\
\text { Jam; Liquor }\end{array}$ & 3 & 10 \\
\hline
\end{tabular}


This is postprint version of the article:

Mattalia, G., Sõukand, R., Corvo, P., \& Pieroni, A. (2019). Scholarly vs. Traditional Knowledge: Effects of Sacred Natural Sites on Ethnobotanical Practices in Tuscany, Central Italy. Human Ecology, 47(5), 653-667.

\begin{tabular}{|c|c|c|c|c|c|}
\hline $\begin{array}{l}\text { UNISGTOS019 } \\
\text { Albatrella, Baciulle }\end{array}$ & $\begin{array}{l}\text { Fruits } \\
\text { and } \\
\text { leaves }\end{array}$ & & $\begin{array}{l}\text { M: Infusion to treat } \\
\text { the liver }\end{array}$ & & 1 \\
\hline $\begin{array}{l}\text { Arundo donax L. (Poaceae) } \\
\text { UNISGTOS027 } \\
\text { Canna }\end{array}$ & $\begin{array}{l}\text { Bark } \\
\text { and } \\
\text { roots }\end{array}$ & $\begin{array}{lr}\text { M: To } & \text { make } \\
\text { ointment } & \text { for } \\
\text { burns; } & \text { Infusion } \\
\text { with other taxa to } \\
\text { treat } & \text { kidney } \\
\text { stones } & \end{array}$ & & 4 & \\
\hline $\begin{array}{l}\text { Asparagus acutifolius L. (Asparagaceae) } \\
\text { UNISGTOS026 } \\
\text { Asparago }\end{array}$ & Stems & $\begin{array}{l}\text { F: Cooked in } \\
\text { risotto or pasta }\end{array}$ & $\begin{array}{l}\text { F: Cooked with } \\
\text { eggs or in omelets; } \\
\text { Boiled; Cooked in } \\
\text { risotto or pasta }\end{array}$ & 5 & 11 \\
\hline $\begin{array}{l}\text { Bellis perennis L. (Asteraceae) } \\
\text { UNISGTOS033 } \\
\text { Margheritine }\end{array}$ & Leaves & & F: Raw in salads & & 1 \\
\hline $\begin{array}{l}\text { Beta vulgaris L. (Amaranthaceae) } \\
\text { Bieta selvatica }\end{array}$ & $\begin{array}{l}\text { Aerial } \\
\text { parts }\end{array}$ & $\begin{array}{l}\text { F: Mixed soups; } \\
\text { Boiled }\end{array}$ & F: Boiled & 5 & 2 \\
\hline $\begin{array}{l}\text { Borago officinalis L. (Boraginaceae) } \\
\text { UNISGTOS028 }\end{array}$ & $\begin{array}{l}\text { Aerial } \\
\text { parts }\end{array}$ & F: Batter-fried & $\begin{array}{l}\text { F: Batter-fried; } \\
\text { Raw in salads; } \\
\text { Boiled and eaten in } \\
\text { salads; Soups }\end{array}$ & 1 & 8 \\
\hline Boraggine & & $\begin{array}{l}\text { M: Infusion to } \\
\text { treat colic }\end{array}$ & & 1 & \\
\hline $\begin{array}{l}\text { Calendula officinalis L. (Asteraceae) } \\
\text { Calendula }\end{array}$ & $\begin{array}{l}\text { Flowers } \\
\text { and } \\
\text { leaves }\end{array}$ & & $\mathrm{F}$ : Raw in salads & & 2 \\
\hline $\begin{array}{l}\text { Campanula } \\
\text { (Campanulaceae) }\end{array}$ & $\begin{array}{l}\text { Aerial } \\
\text { parts or } \\
\text { roots }\end{array}$ & F: Raw in salads & & 5 & \\
\hline $\begin{array}{l}\text { Capparis spinosa L. (Capparidaceae) } \\
\text { Cappero }\end{array}$ & Fruits & F: Seasoning & F: Seasoning & 3 & 1 \\
\hline $\begin{array}{l}\text { Ceterach officinarum } \\
\text { (Aspleniaceae) }\end{array}$ & & $\begin{array}{l}\text { M: Infusion to } \\
\text { treat inflammation }\end{array}$ & $\begin{array}{l}\text { M: Infusion to treat } \\
\text { the kidneys and } \\
\text { kidney stones }\end{array}$ & 2 & 3 \\
\hline
\end{tabular}


This is postprint version of the article:

Mattalia, G., Sõukand, R., Corvo, P., \& Pieroni, A. (2019). Scholarly vs. Traditional Knowledge: Effects of Sacred Natural Sites on Ethnobotanical Practices in Tuscany, Central Italy. Human Ecology, 47(5), 653-667.

\begin{tabular}{|c|c|c|c|c|c|}
\hline $\begin{array}{l}\text { Chamaemelum nobilis All. (Asteraceae) } \\
\text { Camomilla romana }\end{array}$ & $\begin{array}{l}\text { Aerial } \\
\text { parts }\end{array}$ & & $\begin{array}{l}\text { M: Infusion as mild } \\
\text { sedative }\end{array}$ & & 1 \\
\hline $\begin{array}{l}\text { Cichorium intybus L. (Asteraceae) } \\
\text { UNISGTOS010 }\end{array}$ & \multirow{2}{*}{$\begin{array}{l}\text { Aerial } \\
\text { parts } \\
\text { and } \\
\text { roots }\end{array}$} & & $\begin{array}{l}\text { F: Boiled and stir- } \\
\text { fried; Raw with } \\
\text { chili pepper }\end{array}$ & & 10 \\
\hline Radicchio, Cicoria, Lattuga selvatica & & & $\begin{array}{l}\text { M: Infusion to } \\
\text { refresh the liver }\end{array}$ & & 2 \\
\hline Clematis vitalba L. (Ranuncolaceae) & \multirow{2}{*}{$\begin{array}{l}\text { Shoots } \\
\text { and } \\
\text { flowers }\end{array}$} & F: Omelets & F: Omelets & 3 & 8 \\
\hline $\begin{array}{l}\text { UNISGTOS008 } \\
\text { Vitalba }\end{array}$ & & & $\begin{array}{l}\text { M: Flower in the } \\
\text { nostrils to treat } \\
\text { headache }\end{array}$ & & 1 \\
\hline $\begin{array}{llll}\text { Clinopodium nepeta } & \text { (L.) } & \text { Kuntze } \\
\text { (Lamiaceae) } & & & \\
\text { Nepetella } & & & \end{array}$ & $\begin{array}{l}\text { Aerial } \\
\text { parts }\end{array}$ & F: Seasoning & F: Seasoning & 2 & 2 \\
\hline $\begin{array}{l}\text { Cornus mas L. (Cornaceae) } \\
\text { UNISGTOS034 } \\
\text { Corniolo }\end{array}$ & \multicolumn{2}{|l|}{ Fruits } & \multicolumn{2}{|l|}{ F: Raw as a snack } & 1 \\
\hline $\begin{array}{l}\text { Corylus avellana L. (Betulaceae) } \\
\text { Nocciola }\end{array}$ & Fruits & F: Raw & F: Raw & 3 & 1 \\
\hline \multirow{2}{*}{$\begin{array}{l}\text { Crataegus monogyna Jacq. (Rosaceae) } \\
\text { Biancospino }\end{array}$} & \multirow{2}{*}{$\begin{array}{l}\text { Fruits } \\
\text { and } \\
\text { flowers }\end{array}$} & F: Raw in salads & F: Raw in salads & 2 & 1 \\
\hline & & $\begin{array}{l}\text { M: Infusion as a } \\
\text { sleep inducer }\end{array}$ & & 1 & \\
\hline $\begin{array}{l}\text { Cupressus spp. (Cupressaceae) } \\
\text { Cipresso }\end{array}$ & Fruits & & $\begin{array}{l}\text { M: In the pocket to } \\
\text { treat flu }\end{array}$ & & 1 \\
\hline $\begin{array}{l}\text { Crepis sancta (L.) Bornm. } \\
\text { (Asteraceae) } \\
\text { Mestolino }\end{array}$ & $\begin{array}{l}\text { Aerial } \\
\text { parts }\end{array}$ & F: Raw in salads & & 1 & \\
\hline $\begin{array}{l}\text { Cynara scolymus L. (Asteraceae) } \\
\text { Carciofo }\end{array}$ & Leaves & $\begin{array}{l}\text { M: Infusion to } \\
\text { treat inflammation }\end{array}$ & $\begin{array}{l}\text { M: Infusion to treat } \\
\text { inflammation; } \\
\text { Infusion to treat the } \\
\text { liver }\end{array}$ & 5 & 1 \\
\hline $\begin{array}{l}\text { Cynodon dactylon (L.) Pers.(Poaceae) } \\
\text { UNISGTOS005 } \\
\text { Gramigna }\end{array}$ & Roots & $\begin{array}{l}\text { M: Infusion to } \\
\text { treat } \\
\text { inflammation; } \\
\text { Infusion to treat } \\
\text { the kidneys and } \\
\text { cystitis }\end{array}$ & $\begin{array}{l}\text { M: Infusion to treat } \\
\text { inflammation; } \\
\text { Infusion as a detox }\end{array}$ & 5 & 6 \\
\hline
\end{tabular}


This is postprint version of the article:

Mattalia, G., Sõukand, R., Corvo, P., \& Pieroni, A. (2019). Scholarly vs. Traditional Knowledge: Effects of Sacred Natural Sites on Ethnobotanical Practices in Tuscany, Central Italy. Human Ecology, 47(5), 653-667.

\begin{tabular}{|c|c|c|c|c|c|}
\hline Cydonia oblonga Mill. (Rosaceae) & Fruits & F: Jam & F: Jam & 3 & 1 \\
\hline $\begin{array}{l}\text { Dioscorea communis (L.) Caddick and } \\
\text { Wilkin. (Dioscoreaceae) } \\
\text { UNISGTOS003 } \\
\text { Tamice }\end{array}$ & Roots & & $\begin{array}{l}\text { M: Rubbed on joint } \\
\text { to reactivate blood } \\
\text { flow to treat } \\
\text { articular pain }\end{array}$ & & 1 \\
\hline $\begin{array}{l}\text { Eucalyptus spp. (Myrthaceae) } \\
\text { Eucalipto }\end{array}$ & Leaves & & $\begin{array}{l}\text { M: } r \text { Poultice } \\
\text { applied on the } \\
\text { chest to remove } \\
\text { catarrh }\end{array}$ & & 1 \\
\hline $\begin{array}{l}\text { Equisetum arvense L. (Equisetaceae) } \\
\text { UNISGTOS001 } \\
\text { Setolino }\end{array}$ & $\begin{array}{l}\text { Aerial } \\
\text { parts }\end{array}$ & $\begin{array}{l}\text { M: Decoction to } \\
\text { treat the kidneys }\end{array}$ & & 2 & \\
\hline $\begin{array}{l}\text { Ficus carica L. (Moraceae) } \\
\text { Fico }\end{array}$ & Fruits & $\begin{array}{l}\text { F: Raw; Dried; } \\
\text { Jam }\end{array}$ & F: Raw; Dried; Jam & 8 & 8 \\
\hline & & $\begin{array}{l}\text { F: Seasoning (for } \\
\text { finocchiata and } \\
\text { fegatelli) }\end{array}$ & $\begin{array}{l}\text { F: Seasoning (for } \\
\text { finocchiata and } \\
\text { fegatelli); Raw in } \\
\text { salads; Stir-fried }\end{array}$ & 13 & 10 \\
\hline $\begin{array}{l}\text { Foeniculum vulgare Mill. (Apiaceae) } \\
\text { UNISGTOS025 } \\
\text { Finocchietto, Finocchiello }\end{array}$ & & $\begin{array}{l}\text { M: Infusion to } \\
\text { treat abdominal } \\
\text { pain; Infusion as a } \\
\text { diuretic }\end{array}$ & $\begin{array}{l}\text { M: Infusion to treat } \\
\text { bronchitis; } \\
\text { Infusion to treat } \\
\text { cough; Infusion to } \\
\text { treat abdominal } \\
\text { pain; Infusion as } \\
\text { a diuretic; Infusion } \\
\text { as a refresher; } \\
\text { Infusion to treat the } \\
\text { kidneys }\end{array}$ & 4 & 8 \\
\hline $\begin{array}{l}\text { Fragaria vesca } \text { L. (Rosaceae) } \\
\text { UNISGTOS013 } \\
\text { Fragolina }\end{array}$ & Fruits & & F: Raw & & 2 \\
\hline $\begin{array}{l}\text { Helichrysum italicum (Roth) G.Don } \\
\text { (Asteraceae) } \\
\text { UNISGTOS002 } \\
\text { Fiori gialli }\end{array}$ & $\begin{array}{l}\text { Aerial } \\
\text { parts }\end{array}$ & & $\begin{array}{l}\text { M: Infusion to treat } \\
\text { cough; Infusion to } \\
\text { treat inflammation; } \\
\text { As a panacea* }\end{array}$ & & 6 \\
\hline
\end{tabular}


This is postprint version of the article:

Mattalia, G., Sõukand, R., Corvo, P., \& Pieroni, A. (2019). Scholarly vs. Traditional Knowledge: Effects of Sacred Natural Sites on Ethnobotanical Practices in Tuscany, Central Italy. Human Ecology, 47(5), 653-667.

\begin{tabular}{|c|c|c|c|c|c|}
\hline $\begin{array}{l}\text { Humulus lupulus L. (Cannabaceae) } \\
\text { Luppolo selvatico }\end{array}$ & Shoots & & $\begin{array}{l}\text { M: Infusion as a } \\
\text { sleep inducer }\end{array}$ & & 2 \\
\hline $\begin{array}{l}\text { Hypericum perforatum L. (Hypericaceae) } \\
\text { UNISGTOS018 } \\
\text { Iperico }\end{array}$ & $\begin{array}{l}\text { Aerial } \\
\text { parts }\end{array}$ & & $\begin{array}{l}\text { M: Maceration in } \\
\text { olive oil to treat } \\
\text { burns }\end{array}$ & & 2 \\
\hline $\begin{array}{l}\text { Juglans regia L. (Juglandaceae) } \\
\text { Noce }\end{array}$ & Fruits & $\begin{array}{l}\text { F: Raw; Filling for } \\
\text { dried figs; } \\
\text { Seasoning; Liquor }\end{array}$ & F: Raw; Liquor & 5 & 6 \\
\hline $\begin{array}{l}\text { Juniperus communis L. (Cupressaceae) } \\
\text { Ginepro }\end{array}$ & Berries & F: Seasoning & F: Seasoning & 1 & 6 \\
\hline $\begin{array}{l}\text { Knautia arvensis } \\
\text { (Caprifoliaceae) }\end{array}$ & Roots & $\begin{array}{l}\text { M: Infusion with } \\
\text { other taxa to treat } \\
\text { kidney stones }\end{array}$ & & 4 & \\
\hline $\begin{array}{l}\text { Lactuca serriola L. (Asteraceae) } \\
\text { Lattughina }\end{array}$ & Leaves & F: Boiled & F: Raw in salads & 4 & 7 \\
\hline \multirow{2}{*}{$\begin{array}{l}\text { Laurus nobilis L. (Lauraceae) } \\
\text { UNISGTOS035 } \\
\text { Lauro, Alloro }\end{array}$} & \multirow[b]{2}{*}{ Leaves } & F: Seasoning & F: Seasoning & 4 & 1 \\
\hline & & $\begin{array}{l}\text { M: Infusion as a } \\
\text { detox }\end{array}$ & & 1 & \\
\hline $\begin{array}{l}\text { Malus spp. (Rosaceae) } \\
\text { Mela }\end{array}$ & Fruits & F: Raw & F: Raw & 3 & 1 \\
\hline & \multirow[b]{2}{*}{$\begin{array}{l}\text { Fresh } \\
\text { or dried } \\
\text { aerial } \\
\text { parts } \\
\text { and } \\
\text { roots }\end{array}$} & $\begin{array}{l}\text { F: Cooked with } \\
\text { pasta }\end{array}$ & & 1 & \\
\hline $\begin{array}{l}\text { Malva sylvestris L. (Malvaceae) } \\
\text { UNISGTOS007 } \\
\text { Malva }\end{array}$ & & $\begin{array}{l}\text { M: Infusion to } \\
\text { treat the intestine; } \\
\text { Infusion to treat } \\
\text { inflammation; } \\
\text { Infusion to treat } \\
\text { sore throat; } \\
\text { Infusion to treat } \\
\text { the kidneys; } \\
\text { Decoction as a } \\
\text { panacea; Infusion } \\
\text { for personal } \\
\text { cleansing; } \\
\text { Mouthwash }\end{array}$ & $\begin{array}{l}\text { M: Infusion to treat } \\
\text { inflammation; } \\
\text { Mouthwash; } \\
\text { Poultice applied on } \\
\text { the chest to remove } \\
\text { catarrh; Infusion to } \\
\text { treat bronchitis; } \\
\text { Infusion as a detox }\end{array}$ & 12 & 12 \\
\hline \multirow[t]{2}{*}{$\begin{array}{l}\text { Matricaria chamomilla L.(Asteraceae) } \\
\text { UNISGTOS004 } \\
\text { Camomilla }\end{array}$} & \multirow[t]{2}{*}{$\begin{array}{l}\text { Aerial } \\
\text { parts }\end{array}$} & $\begin{array}{l}\text { M: Infusion to } \\
\text { treat the stomach; } \\
\text { Infusion and } \\
\text { locally applied to } \\
\text { treat the eyes }\end{array}$ & $\begin{array}{l}\text { M: Infusion as a } \\
\text { mild sedative; } \\
\text { Infusion to treat } \\
\text { inflammation }\end{array}$ & 10 & 14 \\
\hline & & & F: Recreational tea & & 1 \\
\hline
\end{tabular}


This is postprint version of the article:

Mattalia, G., Sõukand, R., Corvo, P., \& Pieroni, A. (2019). Scholarly vs. Traditional Knowledge: Effects of Sacred Natural Sites on Ethnobotanical Practices in Tuscany, Central Italy. Human Ecology, 47(5), 653-667.

\begin{tabular}{|c|c|c|c|c|c|}
\hline $\begin{array}{l}\text { Melissa officinalis L. (Lamiaceae) } \\
\text { Melissa }\end{array}$ & $\begin{array}{l}\text { Aerial } \\
\text { part }\end{array}$ & $\begin{array}{l}\text { M: Infusion as a } \\
\text { detox }\end{array}$ & $\begin{array}{l}\text { M: To keep } \\
\text { mosquitos away }\end{array}$ & 1 & 1 \\
\hline $\begin{array}{l}\text { Mentha spp. (Lamiaceae) } \\
\text { UNISGTOS006 } \\
\text { Menta, Mentuccia }\end{array}$ & Leaves & F: Seasoning & $\begin{array}{l}\text { F: Seasoning; } \\
\text { Recreational tea; } \\
\text { Liquor }\end{array}$ & 1 & 5 \\
\hline $\begin{array}{l}\text { Mespilus germanica L. (Rosaceae) } \\
\text { Manzeolo }\end{array}$ & Fruits & & F: Raw & & 1 \\
\hline $\begin{array}{l}\text { Morus nigra L. (Moraceae) } \\
\text { Mora d'Olmo }\end{array}$ & Fruits & & F: Jam; Raw & & 3 \\
\hline $\begin{array}{l}\text { Myrtus communis L. (Myrtaceae) } \\
\text { Mirto }\end{array}$ & Fruits & & $\begin{array}{l}\text { F: Liquor*; } \\
\text { Seasoning }\end{array}$ & & 1 \\
\hline $\begin{array}{l}\text { Nasturtium officinale R.Br. (Brassicaceae) } \\
\text { Crescione d'acqua }\end{array}$ & $\begin{array}{l}\text { Aerial } \\
\text { parts }\end{array}$ & & F: Raw in salad & & 1 \\
\hline $\begin{array}{l}\text { Olea europaea L. (Oleaceae) } \\
\text { Ulivo }\end{array}$ & Leaves & $\begin{array}{l}\text { M: Ointment with } \\
\text { other taxa to treat } \\
\text { burns }\end{array}$ & $\begin{array}{l}\text { M: Infusion as a } \\
\text { detox }\end{array}$ & 2 & 1 \\
\hline $\begin{array}{l}\text { Oxalis acetosella L. (Oxalidaceae) } \\
\text { UNISGTOSO23 }\end{array}$ & $\begin{array}{l}\text { Aerial } \\
\text { parts }\end{array}$ & & F: Raw in salads & & 2 \\
\hline $\begin{array}{l}\text { Papaver rhoeas L. (Papaveraceae) } \\
\text { UNISGTOS017 } \\
\text { Rosolaccio }\end{array}$ & $\begin{array}{l}\text { Aerial } \\
\text { parts }\end{array}$ & & $\begin{array}{l}\text { F: Omelette; Raw } \\
\text { in salads; Boiled } \\
\text { and eaten in salads }\end{array}$ & & 8 \\
\hline $\begin{array}{l}\text { Papaver somniferum L.(Papaveraceae) * } \\
\text { Rosolaccio }\end{array}$ & $\begin{array}{l}\text { Seed } \\
\text { pods }\end{array}$ & & $\begin{array}{ll}\text { M: } & \text { Sleep } \\
\text { inducing* } & \end{array}$ & & 1 \\
\hline $\begin{array}{l}\text { Plantago lanceolata L. (Plantaginaceae) } \\
\text { UNISGTOS009 } \\
\text { Orecchie di lepre }\end{array}$ & Leaves & & $\begin{array}{l}\text { F: Raw in salads } \\
\text { M: Locally applied } \\
\text { as an anticoagulant }\end{array}$ & & 1 \\
\hline $\begin{array}{l}\text { Polypodium vulgare L. (Polypodiaceae)* } \\
\text { Felci che sanno di liquirizia }\end{array}$ & Roots & & $\begin{array}{l}\text { M: Infusion to treat } \\
\text { inflammation }\end{array}$ & & 2 \\
\hline
\end{tabular}


This is postprint version of the article:

Mattalia, G., Sõukand, R., Corvo, P., \& Pieroni, A. (2019). Scholarly vs. Traditional Knowledge: Effects of Sacred Natural Sites on Ethnobotanical Practices in Tuscany, Central Italy. Human Ecology, 47(5), 653-667.

\begin{tabular}{|c|c|c|c|c|c|}
\hline $\begin{array}{l}\text { Prunus cerasus L. (Rosaceae) } \\
\text { Ciliegio }\end{array}$ & Fruits & F: Jam & $\begin{array}{l}\text { F: Jam; } \\
\text { with } \\
\text { Liquorerved }\end{array}$ & 5 & 6 \\
\hline $\begin{array}{l}\text { Prunus domestica L. (Rosaceae) } \\
\text { Prugno, Susino }\end{array}$ & Fruits & F: Jam; Raw & F: Jam; Raw & 8 & 5 \\
\hline $\begin{array}{l}\text { Prunus dulcis (Mill.) } \\
\text { (Rosaceae) } \\
\text { Mandorlo }\end{array}$ & Fruits & F: Raw & & 4 & \\
\hline $\begin{array}{l}\text { Prunus persica (L.) Batsch (Rosaceae) } \\
\text { Pesca }\end{array}$ & Fruits & F: Jam; Raw & & 4 & \\
\hline $\begin{array}{l}\text { Pyrus spp.(Rosaceae) } \\
\text { UNISGTOS012 } \\
\text { Pera }\end{array}$ & Fruits & F: Raw; Jam & & 3 & \\
\hline $\begin{array}{l}\text { Quercus spp.* (Fagaceae) } \\
\text { Quercia }\end{array}$ & Acorns & & $\begin{array}{l}\text { F: Boiled and } \\
\text { ground to make } \\
\text { bread }\end{array}$ & & 1 \\
\hline $\begin{array}{l}\text { Reichardia picroides (L.) Roth } \\
\text { (Asteraceae) } \\
\text { UNISGTOS036 } \\
\text { Terracrepoli Tornacrepoli }\end{array}$ & $\begin{array}{l}\text { Aerial } \\
\text { parts }\end{array}$ & F: Raw in salads & F: Raw in salads & 13 & 9 \\
\hline $\begin{array}{l}\text { Robinia pseudoacacia L. (Leguminosae) } \\
\text { UNISGTOS030 }\end{array}$ & Flowers & F: Batter-fried & $\begin{array}{l}\text { F: Batter-fried; } \\
\text { Sauce for pasta; } \\
\text { Recreational tea }\end{array}$ & 5 & 8 \\
\hline Acacia, Robinia & $\begin{array}{l}\text { Bark } \\
\text { and } \\
\text { flowers }\end{array}$ & & $\begin{array}{l}\text { M: Infusion to } \\
\text { reduce fever }\end{array}$ & & 2 \\
\hline Rosa canina L. (Rosaceae) & & F: Jam & F: Omelets & 1 & 3 \\
\hline $\begin{array}{l}\text { UNISGTOS020 } \\
\text { Rosa Canina }\end{array}$ & $\begin{array}{l}\text { Fruits } \\
\text { and } \\
\text { shoots }\end{array}$ & & $\begin{array}{l}\text { M: Decoction ("it's } \\
\text { healthy") }\end{array}$ & & 1 \\
\hline Rosmarinus officinalis L. (Lamiaceae) & & F: Seasoning & F: Seasoning & 6 & 8 \\
\hline $\begin{array}{l}\text { UNISGTOS032 } \\
\text { Ramelino }\end{array}$ & $\begin{array}{l}\text { Aerial } \\
\text { parts }\end{array}$ & $\begin{array}{l}\text { M: Fomentation to } \\
\text { treat flu }\end{array}$ & & 2 & \\
\hline Rubus ulmifolius Schott (Rosaceae) & Fruits & F: Jam; Raw & F: Jam; Raw & 8 & 13 \\
\hline $\begin{array}{l}\text { UNISGTOS033 } \\
\text { Rogo }\end{array}$ & Shoots & $\begin{array}{l}\text { F: Omelets } \\
\text { M: To make } \\
\text { ointment for burns }\end{array}$ & F: Omelets & 2 & 3 \\
\hline
\end{tabular}


This is postprint version of the article:

Mattalia, G., Sõukand, R., Corvo, P., \& Pieroni, A. (2019). Scholarly vs. Traditional Knowledge: Effects of Sacred Natural Sites on Ethnobotanical Practices in Tuscany, Central Italy. Human Ecology, 47(5), 653-667.

\begin{tabular}{|c|c|c|c|c|c|}
\hline $\begin{array}{l}\text { Rumex crispus L. (Polygonaceae) } \\
\text { UNISGTOS } 022 \\
\text { Rombicione }\end{array}$ & Roots & $\begin{array}{l}\text { M: Infusion with } \\
\text { other taxa to treat } \\
\text { kidney stones }\end{array}$ & & 2 & \\
\hline $\begin{array}{l}\text { Ruscus aculeatus L. (Asparagaceae) } \\
\text { UNISGTOS015 } \\
\text { Pungitopi }\end{array}$ & Stem & F: Omelets; Boiled & F: Omelets; Boiled & 3 & 5 \\
\hline Ruta graveolens L. (Rutaceae) & & & F: Liquor & & 2 \\
\hline Ruta & Leaves & & $\begin{array}{l}\text { M: Anti- } \\
\text { helminthic* }\end{array}$ & & 1 \\
\hline & & $\begin{array}{l}\text { F: Seasoning; } \\
\text { Batter-fried }\end{array}$ & $\begin{array}{l}\text { F: Seasoning; } \\
\text { Batter-fried }\end{array}$ & 6 & 11 \\
\hline $\begin{array}{l}\text { Salvia spp. (Lamiaceae) } \\
\text { UNISGTOS021 } \\
\text { Salvia }\end{array}$ & Leaves & $\begin{array}{l}\text { M: Infusion to } \\
\text { treat stomach pain; } \\
\text { Infusion to treat } \\
\text { mouth } \\
\text { inflammation }\end{array}$ & $\begin{array}{l}\text { M: Infusion to } \\
\text { wash hair; Infusion } \\
\text { as a detox; Infusion } \\
\text { with lemon to treat } \\
\text { sore throat; } \\
\text { Infusion to treat } \\
\text { mouth } \\
\text { inflammation }\end{array}$ & 8 & 10 \\
\hline $\begin{array}{l}\text { Sambucus nigra L. (Adoxaceae) } \\
\text { UNISGTOS031 } \\
\text { Sambuco }\end{array}$ & $\begin{array}{l}\text { Leaves } \\
\text { and } \\
\text { flowers }\end{array}$ & $\begin{array}{l}\text { F: Batter-fried; } \\
\text { Raw in salads }\end{array}$ & $\begin{array}{lr}\text { F: } & \text { Recreational } \\
\text { tea; } & \text { Seasoning; } \\
\text { Juice } & \end{array}$ & 4 & 4 \\
\hline $\begin{array}{l}\text { Sanguisorba officinalis L. (Rosaceae) } \\
\text { Pimpinella, Nociarella }\end{array}$ & Leaves & F: Raw in salads & F: Raw in salads & 5 & 1 \\
\hline $\begin{array}{l}\text { Sonchus oleraceaus (L.) L. } \\
\text { (Asteraceae) } \\
\text { Crespino }\end{array}$ & $\begin{array}{l}\text { Aerial } \\
\text { parts }\end{array}$ & F: Raw in salads & F: Raw in salads & 11 & 10 \\
\hline Sorbus domestica L. (Rosaceae) & Fruits & F: Raw & & 5 & \\
\hline $\begin{array}{l}\text { Spartium junceum L. (Leguminosae) } \\
\text { Ginestra }\end{array}$ & Flowers & F: Batter-fried & & 1 & \\
\hline $\begin{array}{l}\text { Taraxacum campylodes G.E.Haglund } \\
\text { (Asteraceae) }\end{array}$ & $\begin{array}{l}\text { Aerial } \\
\text { parts }\end{array}$ & $\begin{array}{l}\text { F: Boiled and then } \\
\text { stir-fried; Raw in } \\
\text { salads }\end{array}$ & $\begin{array}{l}\text { F: Boiled and then } \\
\text { stir-fried; Raw in } \\
\text { salads }\end{array}$ & 5 & 8 \\
\hline
\end{tabular}


This is postprint version of the article:

Mattalia, G., Sõukand, R., Corvo, P., \& Pieroni, A. (2019). Scholarly vs. Traditional Knowledge: Effects of Sacred Natural Sites on Ethnobotanical Practices in Tuscany, Central Italy. Human Ecology, 47(5), 653-667.

\begin{tabular}{|c|c|c|c|c|c|}
\hline $\begin{array}{l}\text { UNISGTOS038 } \\
\text { Insalata matta, Piscialetto, Cardella }\end{array}$ & Roots & $\begin{array}{l}\text { M: Infusion to } \\
\text { treat inflammation }\end{array}$ & $\begin{array}{l}\text { M: Infusion to treat } \\
\text { inflammation }\end{array}$ & 1 & 1 \\
\hline Thymus spp. (Lamiaceae) & $\begin{array}{l}\text { Aerial } \\
\text { parts }\end{array}$ & & F: Seasoning & & 1 \\
\hline $\begin{array}{l}\text { Tragopogon pratensis L.(Asteraceae) } \\
\text { UNISGTOS024 } \\
\text { Barba becco }\end{array}$ & $\begin{array}{l}\text { Aerial } \\
\text { parts }\end{array}$ & F: Raw in salads & & 5 & \\
\hline $\begin{array}{l}\text { Trifolium pratense L. (Leguminosae) } \\
\text { UNISGTOS029 } \\
\text { Trifoglio }\end{array}$ & Flowers & & F: Raw as a snack & & 1 \\
\hline $\begin{array}{l}\text { Ulmus spp. (Ulmaceae) } \\
\text { Olmo }\end{array}$ & Gall & & $\begin{array}{l}\text { M: Infusion as } \\
\text { an antibiotic to } \\
\text { disinfect wounds }\end{array}$ & & 1 \\
\hline \multirow{3}{*}{$\begin{array}{l}\text { Urtica dioica L. (Urticaceae) } \\
\text { Ortica }\end{array}$} & $\begin{array}{l}\text { Aerial } \\
\text { parts }\end{array}$ & $\begin{array}{l}\text { F: Cooked in } \\
\text { risotto; Ravioli } \\
\text { filling; Omelets }\end{array}$ & $\begin{array}{l}\text { F: Cooked in } \\
\text { risotto; Ravioli } \\
\text { filling; Omelets; } \\
\text { Soup }\end{array}$ & 5 & 9 \\
\hline & & $\begin{array}{l}\text { M: Poultice to } \\
\text { wash hair }\end{array}$ & & 1 & \\
\hline & Roots & & F: Sauce for pasta & & 1 \\
\hline $\begin{array}{l}\text { Valerianella spp. (Valerianaceae) } \\
\text { Ceciarelli }\end{array}$ & $\begin{array}{l}\text { Aerial } \\
\text { parts }\end{array}$ & F: Raw in salads & $\begin{array}{l}\text { F: Raw in salads; } \\
\text { Boiled }\end{array}$ & 14 & 12 \\
\hline
\end{tabular}

Table 4 List of recorded taxa and detailed use-reports for the villages of Pratieghi (close) and Badia Prataglia (distant) in the province of Arezzo; * Past uses.

\begin{tabular}{|c|c|c|c|c|c|}
\hline Botanical taxon, family, recorded name & $\begin{array}{l}\text { Parts } \\
\text { used }\end{array}$ & $\begin{array}{l}\text { Uses in } \\
\text { Badia } \\
\text { Prataglia }\end{array}$ & $\begin{array}{l}\text { Uses in } \\
\text { Pratieghi }\end{array}$ & $\begin{array}{l}\text { Badia } \\
\text { Prataglia }\end{array}$ & Pratieghi \\
\hline e & ( & $\begin{array}{l}\text { F: } \\
\text { "Lacrima } \\
\text { di Abeto" } \\
\text { liquor } \\
\text { made by } \\
\text { Camaldoli } \\
\text { monks }\end{array}$ & & 4 & \\
\hline $\begin{array}{l}\text { Abies spp. (Pinaceae) } \\
\text { Abete }\end{array}$ & Resin & $\begin{array}{l}\text { M: Resin } \\
\text { for making } \\
\text { skin softer }\end{array}$ & & 2 & \\
\hline $\begin{array}{l}\text { Arctium lappa L. (Asteraceae) } \\
\text { Bardana }\end{array}$ & Leaves & & $\begin{array}{l}\text { M: Decoction } \\
\text { with mint: "it }\end{array}$ & & 3 \\
\hline
\end{tabular}




\begin{tabular}{|c|c|c|c|c|c|}
\hline & & & $\begin{array}{l}\text { is healthy"; } \\
\text { Decoction for } \\
\text { hair and } \\
\text { dandruff; } \\
\text { Decoction } \\
\text { with nettle and } \\
\text { dandelion: 'it } \\
\text { is healthy' }\end{array}$ & & \\
\hline $\begin{array}{l}\text { Asparagus acutifolius L. (Asparagaceae) } \\
\text { UNISGTOS026 } \\
\text { Asparagi selvatici }\end{array}$ & Stems & $\begin{array}{l}\text { F: } \\
\text { Omelets; } \\
\text { Boiled }\end{array}$ & & 3 & \\
\hline $\begin{array}{l}\text { Atropa belladonna L. (Solanaceae)* } \\
\text { Belladonna }\end{array}$ & $\begin{array}{l}\text { Aerial } \\
\text { parts }\end{array}$ & & $\begin{array}{l}\text { M: Medicinal } \\
\text { and } \\
\text { poisonous. }\end{array}$ & & 2 \\
\hline $\begin{array}{l}\text { Borago officinalis L. (Boraginaceae) } \\
\text { UNISGTOS028 } \\
\text { Borragine }\end{array}$ & Flowers & & $\begin{array}{l}\text { F: Raw in } \\
\text { salads }\end{array}$ & & 3 \\
\hline $\begin{array}{l}\text { Campanula rapunculus } \\
\text { L. (Campanulaceae) } \\
\text { Raponzolo }\end{array}$ & Roots & & F: Raw & & 1 \\
\hline $\begin{array}{l}\text { Carlina acaulis L. (Asteraceae) } \\
\text { Carlina }\end{array}$ & Roots & F:Boiled & F: Boiled & 1 & 1 \\
\hline $\begin{array}{l}\text { Castanea sativa Mill. (Fagaceae) } \\
\text { Castagna }\end{array}$ & $\begin{array}{l}\text { Fruits and } \\
\text { leaves }\end{array}$ & $\begin{array}{l}\text { F: Boiled } \\
\text { to make } \\
\text { the local } \\
\text { bread } \\
\text { called } \\
\text { Baldino }\end{array}$ & & 6 & \\
\hline $\begin{array}{l}\text { Cichorium intybus L. } \\
\text { UNISGTOS } 010 \\
\text { Radicchio }\end{array}$ & $\begin{array}{l}\text { Young } \\
\text { sprouts }\end{array}$ & $\begin{array}{l}\text { F: Minced } \\
\text { in salads }\end{array}$ & $\begin{array}{l}\text { F: Minced in } \\
\text { salads }\end{array}$ & 1 & 5 \\
\hline $\begin{array}{l}\text { Clematis vitalba L. (Ranuncolaceae) } \\
\text { UNISGTOS008 } \\
\text { Vitalba }\end{array}$ & Sprouts & $\begin{array}{l}\text { F: } \\
\text { Omelets; } \\
\text { Ravioli } \\
\text { fillings }\end{array}$ & $\begin{array}{l}\text { F: Omelets; } \\
\text { Soups }\end{array}$ & 8 & 7 \\
\hline $\begin{array}{lll}\text { Cornus mas } & \text { L. } & \text { (Cornaceae) } \\
\text { UNISGTOS034 } & & \\
\text { Corniolo } & & \\
\end{array}$ & Fruits & F: Jam & F: Liquor & 1 & 3 \\
\hline $\begin{array}{l}\text { Corylus avellana L. (Betulaceae) } \\
\text { Nocciola }\end{array}$ & Fruits & $\begin{array}{l}\text { F: Raw as } \\
\text { a snack }\end{array}$ & $\begin{array}{l}\text { F: Raw as a } \\
\text { snack }\end{array}$ & 2 & 3 \\
\hline $\begin{array}{l}\text { Crataegus laevigata (Poir.) DC (Rosaceae) } \\
\text { Biancospino }\end{array}$ & Fruits & & F: Liquor & & 3 \\
\hline $\begin{array}{l}\text { Dactylorhiza sambucina (L.) Soó * * } \\
\text { (Orchideaeceae) } \\
\text { Panciachino }\end{array}$ & Bulbs & $\begin{array}{l}\text { F: Raw "as } \\
\text { a snack" }\end{array}$ & & 1 & \\
\hline $\begin{array}{l}\text { Equisetum arvense L. (Equisetaceae)* } \\
\text { UNISGTOSO01 } \\
\text { Coda di cavallo }\end{array}$ & $\begin{array}{l}\text { Aerial } \\
\text { parts }\end{array}$ & & $\begin{array}{l}\text { M: Infusion, } \\
\text { "it's healthy" }\end{array}$ & & 2 \\
\hline $\begin{array}{l}\text { Foeniculum vulgare Miller (Apiaceae) } \\
\text { UNISGTOS025 } \\
\text { Finocchio selvatico }\end{array}$ & $\begin{array}{l}\text { Leaves } \\
\text { and seeds }\end{array}$ & & F: Seasoning & & 1 \\
\hline $\begin{array}{l}\text { Fragaria vesca } \text { L. (Rosaceae) } \\
\text { UNISGTOS013 } \\
\text { Fragoline }\end{array}$ & Fruits & $\begin{array}{l}\text { F: Liquor; } \\
\text { Syrup }\end{array}$ & $\begin{array}{l}\text { F: Jam; Raw } \\
\text { as a snack }\end{array}$ & 6 & 9 \\
\hline $\begin{array}{l}\text { Fraxinus spp. (Oleaceae) } \\
\text { Frassino }\end{array}$ & Flowers & $\begin{array}{l}\text { M: For } \\
\text { treating } \\
\text { skin }\end{array}$ & & 2 & \\
\hline
\end{tabular}


This is postprint version of the article:

Mattalia, G., Sõukand, R., Corvo, P., \& Pieroni, A. (2019). Scholarly vs. Traditional Knowledge: Effects of Sacred Natural Sites on Ethnobotanical Practices in Tuscany, Central Italy. Human Ecology, 47(5), 653-667.

\begin{tabular}{|c|c|c|c|c|c|}
\hline $\begin{array}{lll}\begin{array}{l}\text { Helychrysum italicum } \\
\text { (Asteraceae) }\end{array} & \text { (Roth) } & \text { Don } \\
\text { UNISGTOS002 } & & \\
\text { Pepolino } & & \\
\end{array}$ & Leaves & & F: Seasoning & & 1 \\
\hline $\begin{array}{l}\text { Humulus lupulus L. (Cannabaceae)* } \\
\text { Luppolo selvatico }\end{array}$ & Sprouts & $\begin{array}{l}\text { F: } \\
\text { Omelets; } \\
\text { Boiled }\end{array}$ & & 1 & \\
\hline $\begin{array}{l}\text { Hypericum perforatum L. (Hypericaceae) } \\
\text { UNISGTOS } 018 \\
\text { Iperico }\end{array}$ & Flowers & & $\begin{array}{l}\text { M: Preserved } \\
\text { in olive oil and } \\
\text { locally applied } \\
\text { to treat skin } \\
\text { burns }\end{array}$ & & 1 \\
\hline $\begin{array}{l}\text { Juglans regia L. (Juglandaceae) } \\
\text { Noce }\end{array}$ & $\begin{array}{l}\text { Fruits and } \\
\text { wood }\end{array}$ & $\begin{array}{l}\text { F: Liquor; } \\
\text { Dessert }\end{array}$ & $\begin{array}{l}\text { F: Liquor can } \\
\text { be made green } \\
\text { (when fruit is } \\
\text { not ripe) } \\
\text { which is more } \\
\text { traditional or } \\
\text { white (when } \\
\text { the walnut is } \\
\text { ready and with } \\
\text { only the } \\
\text { kernel) }\end{array}$ & 6 & 11 \\
\hline $\begin{array}{l}\text { Juniperus communis L. (Cupressaceae) } \\
\text { Ginepro }\end{array}$ & Berries & $\begin{array}{l}\text { F: Liquor; } \\
\text { Seasoning } \\
\text { (meat) }\end{array}$ & $\begin{array}{l}\text { F: Seasoning } \\
\text { (wild boar) }\end{array}$ & 3 & 5 \\
\hline $\begin{array}{l}\text { Malus sylvestris Mill. (Rosaceae) } \\
\text { Mela }\end{array}$ & Fruits & $\begin{array}{l}\text { F: Jam; } \\
\text { Raw; } \\
\text { Dessert }\end{array}$ & F: Jam; Raw & 6 & 3 \\
\hline $\begin{array}{l}\text { Malva spp. (Malvaceae) } \\
\text { UNISGTOS007 } \\
\text { Malva }\end{array}$ & $\begin{array}{l}\text { Aerial } \\
\text { parts }\end{array}$ & $\begin{array}{l}\text { M: } \\
\text { Decoction } \\
\text { to treat } \\
\text { toothache; } \\
\text { Infusion to } \\
\text { refresh; } \\
\text { Chewed to } \\
\text { treat } \\
\text { toothache }\end{array}$ & $\begin{array}{l}\text { M: Infusion } \\
\text { for toothache; } \\
\text { It is refreshing } \\
\text { and it relieves } \\
\text { inflammation }\end{array}$ & 7 & 7 \\
\hline $\begin{array}{l}\text { Matricaria chamomilla L. (Asteraceae) } \\
\text { UNISGTOS004 } \\
\text { Camomilla }\end{array}$ & Flowers & $\begin{array}{l}\text { M: } \\
\text { Infusion as } \\
\text { a } \\
\text { calmative }\end{array}$ & $\begin{array}{l}\text { M: Infusion } \\
\text { for sleeping } \\
\text { and treating } \\
\text { abdominal } \\
\text { pain }\end{array}$ & 3 & 4 \\
\hline $\begin{array}{l}\text { Mentha spp. (Lamiaceae) } \\
\text { UNISGTOS006 } \\
\text { Menta }\end{array}$ & Leaves & $\begin{array}{l}\text { F: } \\
\text { Seasoning } \\
\text { (meat) }\end{array}$ & $\begin{array}{l}\text { M: Infusion } \\
\text { for headache }\end{array}$ & 2 & 2 \\
\hline $\begin{array}{l}\text { Mespilus germanica L. (Rosaceae) } \\
\text { Nespolo }\end{array}$ & Fruits & F: Raw & F: Liquor & 1 & 3 \\
\hline $\begin{array}{l}\text { Origanum majorana L. (Lamiaceae) } \\
\text { Maggiorana }\end{array}$ & Leaves & & F: Seasoning & & 1 \\
\hline $\begin{array}{l}\text { Origanum vulgare L. (Lamiaceae) } \\
\text { Origano }\end{array}$ & Leaves & & F: Seasoning & & 1 \\
\hline $\begin{array}{l}\text { Papaver rhoeas L. (Papaveraceae) } \\
\text { UNISGTOS } 017 \\
\text { Rosolaccio }\end{array}$ & Sprouts & & F: Boiled & & 2 \\
\hline $\begin{array}{l}\text { Pinus spp. (Pinaceae) } \\
\text { Pino }\end{array}$ & Buds & $\begin{array}{l}\text { M: Bud } \\
\text { decoction } \\
\text { for cough }\end{array}$ & & 3 & \\
\hline
\end{tabular}


This is postprint version of the article:

Mattalia, G., Sõukand, R., Corvo, P., \& Pieroni, A. (2019). Scholarly vs. Traditional Knowledge: Effects of Sacred Natural Sites on Ethnobotanical Practices in Tuscany, Central Italy. Human Ecology, 47(5), 653-667.

\begin{tabular}{|c|c|c|c|c|c|}
\hline $\begin{array}{l}\text { Plantago lanceolata L. (Plantaginaceae) } \\
\text { UNISGTOS009 } \\
\text { Orecchie di lepre }\end{array}$ & Leaves & & F: Boiled & & 1 \\
\hline $\begin{array}{l}\text { Sanguisorba officinalis L. (Rosaceae) } \\
\text { Pimpinella }\end{array}$ & $\begin{array}{l}\text { Aerial } \\
\text { parts and } \\
\text { seeds }\end{array}$ & $\begin{array}{l}\text { F: Raw in } \\
\text { mixed } \\
\text { salads }\end{array}$ & F: Seasoning & 1 & 2 \\
\hline $\begin{array}{l}\text { Primula vulgaris Huds. (Primulaceae) } \\
\text { Primule }\end{array}$ & $\begin{array}{l}\text { Flowers } \\
\text { and } \\
\text { leaves }\end{array}$ & & $\begin{array}{l}\text { F: Raw in } \\
\text { salads with } \\
\text { lemon/vinegar } \\
\text { and olive oil }\end{array}$ & & 2 \\
\hline $\begin{array}{l}\text { Prunus avium L. (Rosaceae) } \\
\text { Ciliegie selvatiche }\end{array}$ & Fruits & & F: Jam; Raw & & 5 \\
\hline $\begin{array}{l}\text { Prunus cerasus L. (Rosaceae) } \\
\text { Amarena }\end{array}$ & Fruits & & F: Jam; Raw & & 3 \\
\hline $\begin{array}{l}\text { Prunus domestica L. (Rosaceae) } \\
\text { Prugna }\end{array}$ & Fruits & $\begin{array}{l}\text { F: Jam; } \\
\text { Raw }\end{array}$ & F: Jam; Raw & 2 & 7 \\
\hline $\begin{array}{l}\text { Prunus spinosa L. (Rosaceae) } \\
\text { Prugnolo }\end{array}$ & Fruits & F: Liquor* & F: Liquor & 1 & 7 \\
\hline $\begin{array}{l}\text { Pyrus communis L. (Rosaceae) } \\
\text { UNISGTOS } 012 \\
\text { Pera cocomerina/mezza }\end{array}$ & Fruits & F: Raw & F: Raw & 1 & 1 \\
\hline $\begin{array}{l}\text { Pyrus piraster Burgsd. (Rosaceae) } \\
\text { Pera }\end{array}$ & Fruits & $\begin{array}{ll}\text { F: Jam; } \\
\text { Raw }\end{array}$ & F: Raw & 6 & 2 \\
\hline \multirow[b]{2}{*}{$\begin{array}{l}\text { Rosa canina L. (Rosaceae) } \\
\text { UNISGTOS } 020 \\
\text { Rosa canina }\end{array}$} & \multirow[b]{2}{*}{ Fruits } & & F: Jam; Raw & & 1 \\
\hline & & & $\begin{array}{l}\text { M: Infusion } \\
\text { for treating flu } \\
\text { and diarrhea }\end{array}$ & & 2 \\
\hline \multirow[b]{2}{*}{$\begin{array}{l}\text { Rubus idaeus L. (Rosaceae) } \\
\text { Lampone }\end{array}$} & \multirow[b]{2}{*}{ Fruits } & $\begin{array}{l}\text { F: Jam; } \\
\text { Raw; } \\
\text { Liquor; } \\
\text { Refreshing } \\
\text { syrup }\end{array}$ & $\begin{array}{l}\text { F: Jam; } \\
\text { Frozen; Raw }\end{array}$ & 9 & 10 \\
\hline & & $\begin{array}{l}\text { M: } \\
\text { Medicinal } \\
\text { syrup } \\
\text { (good for } \\
\text { sore } \\
\text { throat) }\end{array}$ & & 3 & \\
\hline \multirow[b]{2}{*}{$\begin{array}{l}\text { Rubus ulmifolius Schott (Rosaceae) } \\
\text { UNISGTOS033 } \\
\text { More }\end{array}$} & Fruits & $\begin{array}{l}\text { F: Jam; } \\
\text { Raw; } \\
\text { Liquor }\end{array}$ & F: Jam; Raw & 12 & 11 \\
\hline & Leaves & $\begin{array}{l}\text { M: Boiled } \\
\text { leaves for } \\
\text { treating } \\
\text { skin } \\
\text { infections }\end{array}$ & & 2 & \\
\hline $\begin{array}{l}\text { Rumex acetosa L.(Polygonaceae)* } \\
\text { Erba salina }\end{array}$ & Leaves & $\begin{array}{l}\text { F: Raw as } \\
\text { a snack }\end{array}$ & & 2 & \\
\hline $\begin{array}{l}\text { Rumex acetosella L. (Polygonaceae) } \\
\text { Romice }\end{array}$ & Leaves & & $\begin{array}{l}\text { M: Infusion } \\
\text { for treating } \\
\text { hemorrhoids }\end{array}$ & & 3 \\
\hline \multirow[b]{2}{*}{$\begin{array}{l}\text { Sambucus nigra L. (Adoxaceae) } \\
\text { UNISGTOS031 } \\
\text { Sambuco }\end{array}$} & \multirow[b]{2}{*}{$\begin{array}{l}\text { Flowers } \\
\text { and fruits }\end{array}$} & $\begin{array}{l}\text { F: Jam; } \\
\text { Liquor }\end{array}$ & $\begin{array}{l}\text { F: Flowers are } \\
\text { batter-fried; } \\
\text { Fruits for jam }\end{array}$ & 4 & 5 \\
\hline & & $\begin{array}{l}\text { M: } \\
\text { Infusion } \\
\text { ("it's } \\
\text { healthy") }\end{array}$ & & 1 & \\
\hline
\end{tabular}


This is postprint version of the article:

Mattalia, G., Sõukand, R., Corvo, P., \& Pieroni, A. (2019). Scholarly vs. Traditional Knowledge: Effects of Sacred Natural Sites on Ethnobotanical Practices in Tuscany, Central Italy. Human Ecology, 47(5), 653-667.

\begin{tabular}{|c|c|c|c|c|c|}
\hline $\begin{array}{lll}\text { Silene vulgaris } & \text { (Moench) } & \text { Garcke } \\
\text { (Caryophyllaceae) } & & \\
\text { UNISGTOS011 } & & \\
\text { Strigoli; Minuto } & & \\
\end{array}$ & Sprouts & $\begin{array}{l}\text { F: Ravioli } \\
\text { fillings }\end{array}$ & $\begin{array}{l}\text { F: Ravioli and } \\
\text { pasta sauce or } \\
\text { filling; Boiled }\end{array}$ & 3 & 11 \\
\hline $\begin{array}{l}\text { Sonchus arvensis L. (Asteraceae) } \\
\text { UNISGTOS } 037 \\
\text { Graspigna }\end{array}$ & Leaves & & F: Boiled & & 1 \\
\hline $\begin{array}{l}\text { Sorbus domestica L. (Rosaceae) } \\
\text { Sorbo }\end{array}$ & Fruits & F: Raw & & 1 & \\
\hline & & $\begin{array}{l}\text { F: Boiled; } \\
\text { Raw in } \\
\text { salads }\end{array}$ & $\begin{array}{l}\text { F: Minced in } \\
\text { salads with } \\
\text { olive oil and } \\
\text { lemon; In } \\
\text { ravioli fillings } \\
\text { with chard and } \\
\text { nettle } \\
\end{array}$ & 1 & 6 \\
\hline $\begin{array}{l}\text { Taraxacum campylodes G.E.Haglund } \\
\text { (Asteraceae) } \\
\text { UNISGTOS038 } \\
\text { Tarassaco }\end{array}$ & $\begin{array}{l}\text { Roots and } \\
\text { leaves }\end{array}$ & & $\begin{array}{l}\text { M: Boiled } \\
\text { roots for liver } \\
\text { detoxification; } \\
\text { Decoction } \\
\text { with Arctium } \\
\text { lappa (and } \\
\text { dandelion): } \\
\text { "it's healthy" }\end{array}$ & & 2 \\
\hline & & & F: Seasoning & & 1 \\
\hline $\begin{array}{l}\text { Thymus serpyllum L. (Lamiaceae) } \\
\text { Timo }\end{array}$ & Leaves & & $\begin{array}{l}\text { M: Infusion } \\
\text { for treating flu } \\
\text { and the } \\
\text { intestine }\end{array}$ & & 1 \\
\hline $\begin{array}{l}\text { Tilia cordata Mill. (Malvaceae) } \\
\text { Tiglio }\end{array}$ & Flowers & $\begin{array}{l}\text { M: } \\
\text { Refreshing } \\
\text { infusion }\end{array}$ & & 1 & \\
\hline $\begin{array}{l}\text { Tragopogon spp. (Asteraceae) } \\
\text { UNISGTOS024 } \\
\text { Tragopone }\end{array}$ & Roots & & F: Boiled & & 1 \\
\hline & & $\begin{array}{l}\text { F: Ravioli } \\
\text { fillings }\end{array}$ & $\begin{array}{l}\text { F: Ravioli } \\
\text { filling (with } \\
\text { spinach or } \\
\text { chard and } \\
\text { Silene); In } \\
\text { ravioli fillings } \\
\text { with chard and } \\
\text { nettle, } \\
\text { spinach, or } \\
\text { chard } \\
\begin{array}{l}\text { Silene } \\
\text { land }\end{array} \\
\end{array}$ & 9 & 8 \\
\hline $\begin{array}{l}\text { Urtica dioica L. (Urticaceae) } \\
\text { Ortica }\end{array}$ & Sprouts & & $\begin{array}{l}\text { M: Decoction } \\
\text { with Arctium } \\
\text { lappa (and } \\
\text { dandelion): } \\
\text { "it's healthy"; } \\
\text { They cook it } \\
\text { with turkey: } \\
\text { "it's healthy" }\end{array}$ & & 3 \\
\hline & Fruit & $\begin{array}{l}\text { F: Raw; } \\
\text { Jam* }\end{array}$ & & 3 & \\
\hline $\begin{array}{l}\text { Vaccinium myrtillus L. (Ericaceae) } \\
\text { Mirtillo }\end{array}$ & Leaves & $\begin{array}{l}\text { M: } \\
\text { Infusion } \\
\text { for treating }\end{array}$ & & 1 & \\
\hline
\end{tabular}


This is postprint version of the article:

Mattalia, G., Sõukand, R., Corvo, P., \& Pieroni, A. (2019). Scholarly vs. Traditional Knowledge: Effects of Sacred Natural Sites on Ethnobotanical Practices in Tuscany, Central Italy. Human Ecology, 47(5), 653-667.

\begin{tabular}{|c|c|c|c|c|c|}
\hline & & $\begin{array}{l}\text { eye } \\
\text { problems }\end{array}$ & & & \\
\hline $\begin{array}{l}\text { Verbena officinalis L. (Verbenaceae) } \\
\text { Verbena }\end{array}$ & Leaves & & $\begin{array}{l}\text { F: Centerbe } \\
\text { liqueur }\end{array}$ & & 1 \\
\hline $\begin{array}{l}\text { Viola odorata } \mathrm{L} . \\
\text { UNISGTOS014 } \\
\text { Viola mammola }\end{array}$ & $x^{2}$ & $\begin{array}{l}\text { M: } \\
\text { Infusion as } \\
\text { a } \\
\text { refresher; } \\
\text { For cough } \\
\text { and sore } \\
\text { throat }\end{array}$ & & 1 & \\
\hline
\end{tabular}

